\title{
Reactive Oxygen Species in Venous Thrombosis
}

\author{
Clemens Gutmann ${ }^{1}{ }^{\oplus}$, Richard Siow ${ }^{2}$, Adam M. Gwozdz ${ }^{3}$, Prakash Saha ${ }^{3,+}$ and Alberto Smith ${ }^{3,+, *}$ \\ 1 King's British Heart Foundation Centre, King's College London, 125 Coldharbour Lane, \\ London SE5 9NU, UK; clemens.gutmann@kcl.ac.uk \\ 2 Vascular Biology \& Inflammation Section, School of Cardiovascular Medicine \& Sciences, \\ British Heart Foundation of Research Excellence, King's College London, SE1 9NH, UK; \\ richard.siow@kcl.ac.uk \\ 3 Academic Department of Surgery, School of Cardiovascular Medicine \& Sciences, \\ British Heart Foundation of Research Excellence, King's College London, London SE1 7EH, UK; \\ adam.gwozdz@kcl.ac.uk (A.M.G.); Prakash.saha@kcl.ac.uk (P.S.) \\ * Correspondence: alberto.smith@kcl.ac.uk; Tel.: +44-207-188-0216 \\ $\dagger$ These two authors contribute equally to this work.
}

Received: 14 February 2020; Accepted: 4 March 2020; Published: 11 March 2020 updates

\begin{abstract}
Reactive oxygen species (ROS) have physiological roles as second messengers, but can also exert detrimental modifications on DNA, proteins and lipids if resulting from enhanced generation or reduced antioxidant defense (oxidative stress). Venous thrombus (DVT) formation and resolution are influenced by ROS through modulation of the coagulation, fibrinolysis, proteolysis and the complement system, as well as the regulation of effector cells such as platelets, endothelial cells, erythrocytes, neutrophils, mast cells, monocytes and fibroblasts. Many conditions that carry an elevated risk of venous thrombosis, such as the Antiphospholipid Syndrome, have alterations in their redox homeostasis. Dietary and pharmacological antioxidants can modulate several important processes involved in DVT formation, but their overall effect is unknown and there are no recommendations regarding their use. The development of novel antioxidant treatments that aim to abrogate the formation of DVT or promote its resolution will depend on the identification of targets that enable ROS modulation confined to their site of interest in order to prevent off-target effects on physiological redox mechanisms. Subgroups of patients with increased systemic oxidative stress might benefit from unspecific antioxidant treatment, but more clinical studies are needed to bring clarity to this issue.
\end{abstract}

Keywords: DVT; venous thrombosis; reactive oxygen species; oxidative stress; redox regulation; anticoagulation; thrombus resolution; dietary antioxidants; antioxidant defenses

\section{Introduction}

Deep vein thrombosis (DVT) accounts for around 10 million cases of thrombosis per year and is the third most prevalent cardiovascular disease (CVD) after myocardial infarction and stroke. The incidence of DVT increases with age and its complications are ranked among the top causes of death and poor quality of life in western countries [1]. As a complication of DVT, pulmonary embolism is the main driver of DVT-associated mortality. Venous reflux in DVT-damaged veins (post-thrombotic syndrome) is, however, the main driver of DVT-associated morbidity, causing pain, swelling and, when severe, chronic skin ulceration. DVT is therefore a major contributor to the global disease burden [1].

Anticoagulation is the most common approach taken when treating DVT, but although these drugs inhibit thrombus propagation, they are associated with an increased risk of pathological bleeding such as stroke. Anticoagulants also have little effect on resolving existing thrombi, which occurs over time through a natural process of organization. Although enhanced natural thrombus resolution 
is associated with improved long-term outcome [2], interventional (endovascular or open surgery) approaches of thrombus resolution are not always effective and are associated with side effects that limit their use in the majority of patients [3]. The development of novel treatment modalities, which block thrombus formation and/or enhance thrombus resolution but, at the same time, carry fewer side effects, are therefore desirable and will only come from an improved understanding of the regulatory mechanisms involved in these processes.

As discussed in this review, numerous studies have shown that both thrombus formation and its resolution may be regulated by reactive oxygen species (ROS). Certain intracellular ROS, such as superoxide $\left(\mathrm{O}_{2}^{-}\right)$and hydrogen peroxide $\left(\mathrm{H}_{2} \mathrm{O}_{2}\right)$, have physiological functions as second messengers in signalling pathways, while pathologic generation or decreased antioxidant scavenging of extraand intracellular ROS (oxidative stress) lead to damage of proteins, lipids and DNA, resulting in modified functions of these molecules as well as dose-dependent programmed or unprogrammed cell death [4]. ROS are generated as by-products of aerobic respiration within mitochondria [5], during oxidative folding of proteins (endoplasmic reticulum [6]), as well as enzymes of the cytochrome p450 (endoplasmic reticulum and mitochondria [7]), cyclooxygenase (endoplasmic reticulum, nuclear envelope [8]), lipoxygenase (nuclear envelope, cytoplasm [9]) and NADPH oxidase (NOX) family (endoplasmic reticulum, endosomal and plasma membranes [10], Figure 1) [4]. NOX enzymes appear to be the most important source for ROS involved in processes related to DVT. Depending on isotype and cell type, these membrane-bound enzymes release $\mathrm{O}_{2}{ }^{-}$into intra- or extracellular compartments [10]. Superoxide may then react (spontaneously or catalysed by superoxide dismutase) to form $\mathrm{H}_{2} \mathrm{O}_{2}$. If $\mathrm{H}_{2} \mathrm{O}_{2}$ molecules encounter transition metals such as $\mathrm{Fe}^{2+}$ ions, they can be converted into highly reactive hydroxyl radicals $(\bullet \mathrm{OH}$, Fenton Reaction [11]), leading to oxidative damage [4]. Several antioxidant enzymes (superoxide dismutase [12], catalase [13], glutathione peroxidases [14], heme oxygenase [15], thioredoxin system [16]) and small molecule antioxidants (glutathione [17], vitamin A, $\mathrm{C}$ and $\mathrm{E}$ [18]) are produced to scavenge ROS, thereby limiting these detrimental effects [18]. These redox mechanisms are essential for normal physiological homeostasis, but their dysregulation may have pathological consequences. In this review, we provide an overview of how ROS and perturbations in redox homeostasis may be involved in the mechanisms that give rise to the formation and resolution of venous thrombi. We also aim to highlight the clinical potential of targeting these processes.

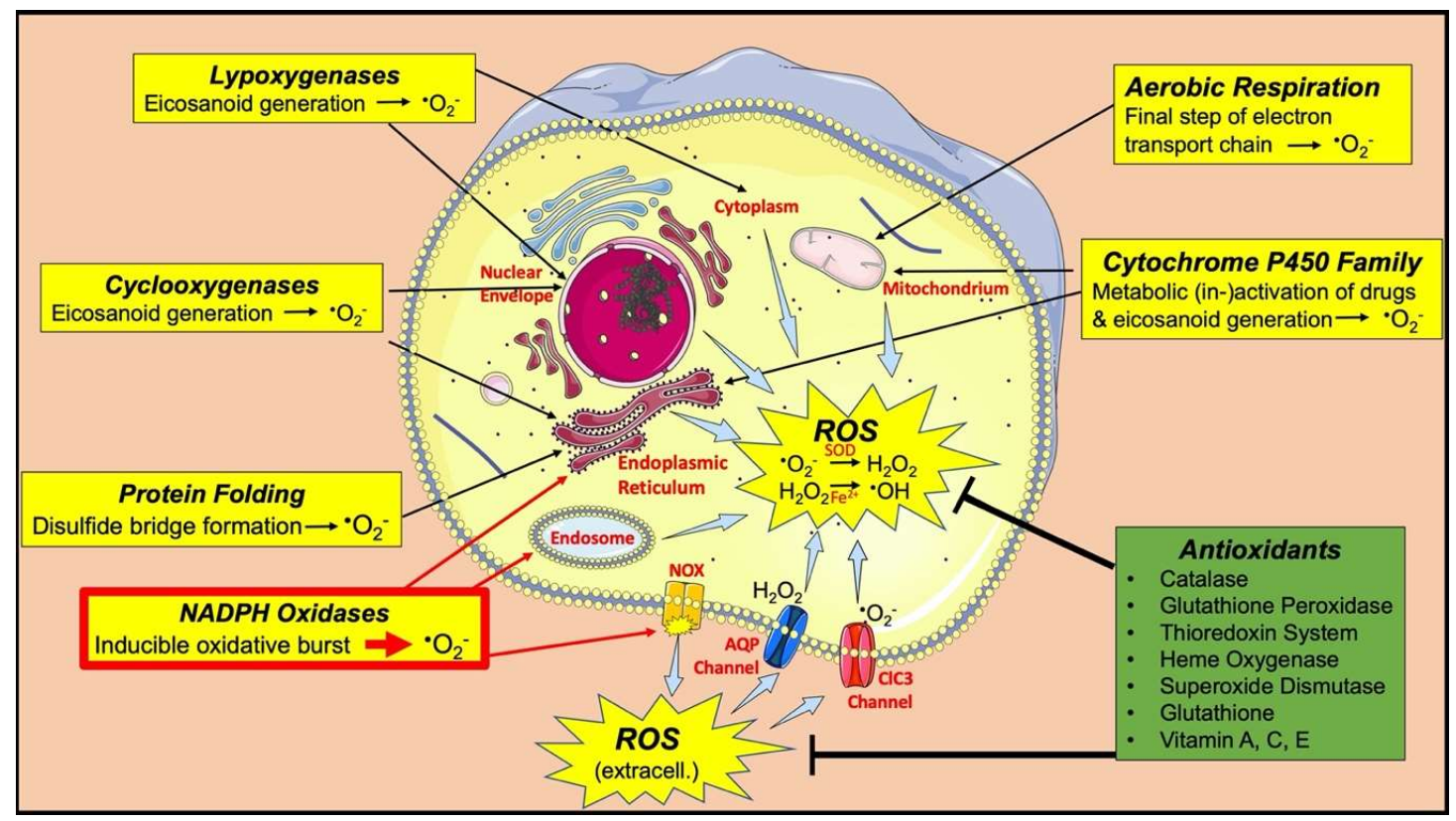

Figure 1. Major sources of reactive oxygen species (ROS) and antioxidant defense mechanisms. NADPH oxidases (NOX; highlighted in red) appear to be the most important source of ROS involved in processes related to the formation and resolution of venous thrombi. 


\section{Venous Thrombus Formation}

The development of a venous thrombus requires activation of the endothelium, platelets and sterile inflammation (involving neutrophils, mast cells and monocytes), stimulated by the interaction between at least two of Virchow's triad of factors: reduced blood flow; endothelial disturbance; and the hypercoagulability of blood. This process leads to the activation of the coagulation cascade with the generation of large amounts of thrombin, converting fibrinogen to fibrin. Venous thrombi have a laminar structure consisting of layers of platelets, leukocytes and fibrin ('lines of Zahn') that encompass the main erythrocyte mass that is very different from the structure of arterial, platelet-rich, "white" thrombi and the amorphous clots of coagulated blood [19]. Leukocytes (neutrophils) can be found attached to the endothelium at the sites of thrombus formation, usually at sites of reduced blood flow such as vein valve pockets and dilated sinuses [20,21]. Activated neutrophils can release neutrophil extracellular traps (NETs), consisting of decondensed chromatin and DNA [22]. These NETs can enhance coagulation through the direct induction of platelet aggregation, erythrocyte recruitment and fibrin deposition [22]); as well as causing endothelial activation and damage [23]. The disrupted and activated endothelial barrier can expose or release prothrombotic proteins, such as collagen, tissue factor, von Willebrand Factor [24,25], and chemotactic proteins, such as cytokines and surface adhesion molecules [26], into the blood, that support further coagulation, platelet aggregation and leukocyte recruitment. Mast cells residing in the vein wall also contribute to venous thrombus formation through endothelial activation and Weibel-Palade body release [27], which, at least in part, is mediated by histamine [28]. The modulation of many of these contributing factors can inhibit thrombus formation. Venous thrombus formation therefore depends on more than just activation of the coagulation cascade, and processes involved in DVT formation other than the coagulation cascade might hold potential for novel treatment options. Identifying pharmacological targets will, however, require an improved understanding of the molecular mechanisms involved in thrombus formation. ROS appear to be important regulators of various processes involved in this phenomenon and the following sections will explore their involvement in more detail (Figure 2).

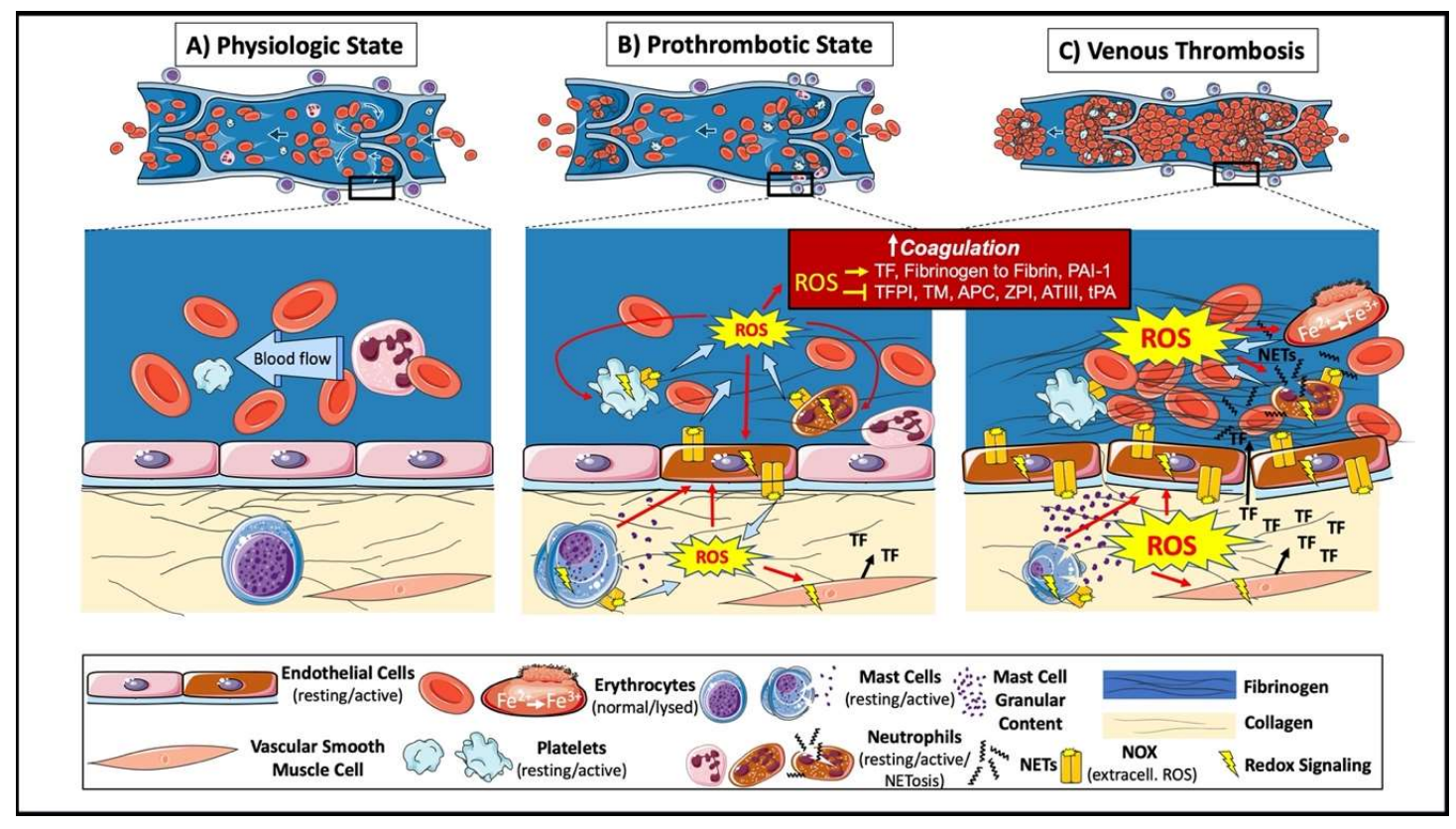

Figure 2. ROS in the formation of a venous thrombus. (A) Physiologic venous circulation. (B) At sites of blood stasis, activated endothelial cells increase ROS luminally (contributing directly and indirectly to recruitment and activation of leukocytes and platelets) and abluminally (contributing directly and indirectly to the activation of mast cells and vascular smooth muscle cells). Activated cells contribute to further ROS generation and use redox signaling to exert their prothrombotic effects, including activation 
of the coagulation system and platelet aggregation; mast cell degranulation and tissue factor (TF) production within the vein wall. (C) Increased coagulability of blood in the presence of low flow (two of Virchow's Triad) provides the environment for venous thrombus formation. In the forming thrombus, erythrocytes (major component) and platelets are entrapped by large amounts of cross-linked fibrin. The oxidative stress leads to oxidation of hemoglobin $\left(\mathrm{Fe}^{2+}\right)$ to methemoglobin $\left(\mathrm{Fe}^{3+}\right)$, resulting in a positive feedback on oxidative stress and thrombus formation. Neutrophil extracellular traps (NETs) provide an additional scaffold and contribute to further oxidative stress and thrombus formation.

\section{ROS and Coagulation}

\subsection{ROS in Signaling Pathways Modulating Procoagulant Responses}

ROS stimulates coagulation by increasing the expression of tissue factor (TF) in endothelial cells [29], monocytes [30] and vascular smooth muscle cells (VSMCs) [31], with ROS-generating NOX enzymes appearing to be important contributors [30-32]. The stimulation of protease-activated receptors (PARs) may also lead to endothelial TF induction via mitochondrial ROS signaling [33]. The coagulation system can also induce the generation of ROS with thrombin, inducing a biphasic ROS increase in endothelial cells, in which the second peak is attributed to transcriptional upregulation of the NOX subunit p22phox via p38 MAPK and PI3K/Akt [34].

\subsection{ROS Oxidative Modification of Proteins That Regulate Coagulation}

ROS may favor a procoagulant state through oxidative modifications of proteins involved in coagulation. Tissue factor pathway inhibitor (TFPI), the only physiologic regulator of TF activity, can be inhibited by oxidative stress and exert a procoagulant effect [35]. ROS can also directly inactivate major anticoagulant proteins, protein C (PC) [36] and its upstream agonist thrombomodulin (TM) [37]. Larger venous thrombi form more rapidly in $\mathrm{SOD}^{--}$mice, which is thought to be caused by reduced SOD1-mediated protein C activation and SOD1-mediated protection of TM [38]. ROS can exert a prothrombotic role by oxidizing fibrinogen, which is then more readily converted to fibrin [39], and reduce the interaction between thrombin and anticoagulants such as protein $C$, the antithrombin III-heparin complex, and TM [40]. The heparin-binding capability of antithrombin is also reduced following oxidation by hydrogen peroxide $\left(\mathrm{H}_{2} \mathrm{O}_{2}\right)$ [41] or lipid peroxides [42]. Oxidized phospholipids suppress the anticoagulant function of the serpin, protein Z-dependent protease inhibitor (ZPI), a specific inhibitor of membrane-associated factor Xa (FXa) that requires protein Z, phospholipid, and calcium as cofactors [43]. Eosinophils have been shown to propagate coagulation, hemostasis and thrombotic disease through 12/15-lipoxygenase-derived oxidized phospholipids [44].

\section{ROS and Platelets}

There is increasing evidence that platelets have a role in the formation of venous thrombi [45], and changes in platelet reactivity affect the risk of DVT [46]. Platelet function is regulated by ROS and impairments in these processes might be responsible for adverse outcomes in patients at risk of developing a DVT.

ROS affects the expression of P-selectin, the circulating levels of which are associated with an increased risk of venous thromboembolism (VTE) [47,48], which may result from its interaction with PSGL1 on neutrophils [49]. The expression of P-selectin [50] and CD40L [51] that are transferred to the platelet surface upon activation is, in part, ROS-dependent. Platelet NOX2 is upregulated and plasma levels of soluble P-selectin and soluble CD40L (sCD40L)are elevated in obese patients who have elevated oxidative stress and an increased risk of DVT [52], while the plasma levels of these proteins are decreased in women with hereditary deficiency of NOX2 [53]. Increased levels of soluble CD40L can enhance platelet activation, aggregation, platelet-leukocyte conjugation and further ROS production [54].

Intraplatelet ROS activates platelets by oxidizing arachidonic acid, thereby generating isoprostanes [55]. Patients with hypercholesterolemia [56], diabetes mellitus [57], homozygous 
homocystinuria [58] and women with obesity [59], have increased circulating levels of isoprostanes associated with persistent platelet activation. Each of these conditions carries an increased risk of DVT $[60,61]$. ROS may also indirectly enhance platelet reactivity by negatively affecting endogenous mechanisms involved in platelet inhibition, such as the scavenging of nitric oxide (NO) that is synthesized by endothelial cells and exerts an anti-platelet aggregating effect [62].

The importance of ROS-mediated effects on platelet activation is evidenced by the diminished activation seen in the presence of antioxidants such as catalase [55], N-acetylcysteine (NAC) [63], polyphenols [64], vitamin C [64], and vitamin E [65], and the increased activation seen in the presence of ROS donors [55]. Knockout of the antioxidant enzyme glutathione peroxidase-3 (GPX-3) results in increased platelet-dependent thrombosis in mice [66], whereas mice overexpressing the GPX-1 isoform were protected from platelet hyperactivity and age-dependent increased susceptibility to experimental venous thrombosis after ligation of the inferior vena cava (IVC) [67].

The essential involvement of NOX enzymes in platelet reactivity is evident from the impaired platelet activation in patients with X-linked chronic granulomatous disease (CGD), characterized by a lack of the NOX subunit gp91phox (NOX2) [55]. Similar observations have been obtained by experimental genetic or pharmacological inhibition of NOX enzymes [55]. Ex vivo investigation of NOX subtype involvement in platelet ROS production and platelet activation revealed that treatment with collagen-related peptide, a GPVI-specific agonist, resulted in NOX1, but not NOX2-dependent ROS production and prothrombotic thromboxane A2 production. NOX1-dependent and NOX2-independent ROS production were also seen upon exposure of platelets to collagen, and ex vivo thrombus formation is impaired in platelets from NOX2 knockout mice [68]. These results hint at a currently unknown ROS-independent function of NOX 2 in platelets, although this may be more plausibly explained by the effects of NOX2 knockout in leukocytes and/or endothelial cells, which could have contributed to thrombus formation and platelet reactivity [68]. In vivo studies show that NOX2 knocked out in both hematopoietic and endothelial cells is crucial for neutrophil-platelet interactions during TNF- $\alpha$-induced venous inflammation that is coupled to thrombosis [50]. Impaired microvascular perfusion in NOX2-deficient mice, occurring through activated coagulation and/or P-selectin-mediated platelet adhesion, is rescued by antioxidant treatment using ascorbate [69]. GPVI stimulation on mouse NOX2-knockout platelets results in reduced ROS generation and platelet activation, while NOX1 knockout platelets showed only selective defects in G-protein-coupled receptor-mediated platelet activation induced by thrombin [70]. Activation of class III phosphoinositide 3-kinase (PI3K) which is important for thrombosis, but dispensable for hemostasis, is also dependent on NOX assembly and subsequent ROS generation [71].

\section{ROS and Extracellular Traps}

The formation of a venous thrombus is particularly dependent on sterile inflammation. One inflammatory mechanism, the release of extracellular traps (NETs), comprised of decondensed chromatin and DNA from activated neutrophils, that was originally thought to be limited to host defense in infection, is also of particular importance to DVT formation [72]. The prothrombotic effect of NETs were initially revealed in experimental models, both in vitro and in vivo [22]. Subsequent studies have confirmed the pathophysiological role of NETs in venous thrombosis, demonstrating their influence on the clotting cascade and identifying essential proteins involved in NETosis [73]. Although extracellular trap formation (ETosis) has mainly been investigated in neutrophils, other immune cells, such as mast cells, eosinophils, and macrophages, have more recently also been shown to release these structures [74]. A role for these sources of ETs in the initiation of DVT remains to be established.

Most pathways resulting in ET release involve signaling by ROS, generated by the phagocyte NADPH homologue, NOX2, which is present in both plasma and phagosome membranes [75]. Many NOX2 activators such as proinflammatory cytokines, lipopolysaccharide (LPS), toll-like receptor (TLR) agonists and chemical agents, such as phorbol 12-myristate 13-acetate (PMA), also trigger NET formation. Neutrophil NOX2 also regulates the function of surface receptors required for 
platelet-neutrophil interactions under thromboinflammatory conditions [50] and this may indirectly favor NETosis, since platelet-neutrophil interactions can induce NETosis through the binding of a P-selectin to its receptor, PSGL-1 [49].

A mechanistic explanation of how ROS enables the initial steps of NETosis, involving intracellular membrane disintegration followed by enzymatic chromatin decondensation, is the ROS-dependent translocation of neutrophil elastase (NE) and myeloperoxidase (MPO) from cytoplasmic azurophilic granules to the nucleus. NE cleaves nucleosomal histones and promotes chromatin decondensation, whereas MPO aids in chromatin decondensation during later stages [76]. Chromatin decondensation is also facilitated by ROS through PAD4-dependent citrullination [77]. The relevance of the ROS-dependent regulation of these processes for DVT formation has been shown in mouse models, with the finding that PAD4-inhibition abrogates NETosis [77], and that $<10 \%$ of PAD4 ${ }^{--}$mice develop venous thrombi $48 \mathrm{hr}$ after IVC ligation, compared with $90 \%$ of wild-type mice [78].

Taken together, the evidence suggests that signaling involved in NETosis requires ROS as second messengers, but also that NETosis may deploy ROS to mediate its extracellular functions. For example, $\mathrm{MPO}$, an ROS-generating enzyme, is among the molecules extruded with NETs. Contrary to this, however, a recent study shows that MPO inhibits phospholipid-dependent coagulation [79], while acquired neutrophil MPO deficiency in man is associated with thrombotic disease [80]. These data suggest a regulatory function on blood coagulation beyond the known oxidative properties of MPO. The contribution of redox signaling in neutrophils to the formation of venous thrombosis would seem appropriate, given the extensive evidence for neutrophil involvement in this pathology. Experimental DVT induction in a conditional NOX2 knockout model would be an example of how this might be achieved.

\section{ROS and Erythrocytes}

Erythrocytes are the main cellular constituent of venous thrombi. Although they are not thought to be major active contributors to DVT formation, some studies suggest that they contribute in a more passive way via oxidative mechanisms. Erythrocytes are enriched in iron as they contain a high amount of the oxygen-transport protein hemoglobin. Increased oxidative stress, as encountered at the sites of venous thrombi, is able to oxidize $\mathrm{Fe}^{2+}$ containing hemoglobin $(\mathrm{Hb})$ to $\mathrm{Fe}^{3+}$-containing methemoglobin. The release of $\mathrm{Fe}^{3+}$ triggers a chain reaction, resulting in further erythrocyte lysis, oxidative stress and thrombus formation [81]. Hemoglobin also upregulates the expression of functional TF in macrophages and desensitizes TF to the effects of antioxidants [82]. Endogenous antioxidant enzymes such as hemeoxygenase-1 (HO-1) counteract this process. This is evident from experimental models that show that HO-1 knockout mice have increased thrombus size at the later stages of thrombus formation [83], while there is a higher risk of recurrent VTE in humans with variations in the HO-1 gene that reduce HO-1 activity [84]. Extracellular heme derived from lysed erythrocytes can also induce NETosis [85], as well as the NLRP3 inflammasome in macrophages via NOX2 [86], both of which may potentiate venous thrombosis [87].

Erythrocytes therefore appear to use oxidative mechanisms to passively promote DVT formation once the process has already started and they are entrapped within the growing thrombus. The degree to which this process is relevant remains unclear, however, as studies suggesting this mechanism were based on in vitro findings [82], performed under artificial oxidative stress in vivo [81] or in sickle cell mice with increased hemolysis [85], or were unable to rule out effects mediated by other cell types that accumulate in the thrombus $[83,84]$.

\section{ROS and Mast Cells}

Mast cells (MCs) represent another sterile inflammation mediator that belongs to the innate immune system and has granules that contain both proinflammatory cytokines such as TNF- $\alpha$ and histamine, as well as antithrombotic factors, such as tissue plasminogen activator (tPA) and heparin [88]. MCs can be found in the wall of blood vessels and are activated and degranulated in response to the 
hypoxia that may follow the stagnation of blood flow in veins [89]. The numbers of MCs close to the sites of venous thrombus formation are reduced, and when depleted prior to thrombus induction, thrombosis is abolished, leading to the suggestion that there is a link between MCs and venous thrombogenesis [27]. A putative mechanism linking MCs with thrombosis involves MC histamine-induced activation of vWF release from endothelial Weibel-Palade bodies, but it is still unclear as to how hypoxia induces activation of MCs [27]. It must be noted, however, that vein wall MC numbers are reported to be increased in DVT patients and express a profibrinolytic phenotype [88].

It is generally accepted that MCs generate ROS and can be activated by ROS $[90,91]$. The inhibition of $\mathrm{MC}$ activation downregulates ROS production, while antioxidants prevent $\mathrm{MC}$ degranulation. $\mathrm{H}_{2} \mathrm{O}_{2}$ mediates the increased susceptibility to DVT in aged mice, whereas overexpression of glutathione peroxidase-1 is protective in mice [67]. NOX2 is a major source of ROS in MCs [92] and ROS activate redox-sensitive calcium channels that facilitate the rise in cytoplasmic calcium needed for $\mathrm{MC}$ degranulation [93].

\section{ROS and the Complement System}

The complement system exerts its effects through an enzymatic cascade similar to the coagulation cascade, with many interactions between these two processes that confer prothrombotic capabilities to this system. High levels of the C3 fragment are associated with a high risk of DVT in man [94], while thrombus weight strongly correlates with C5a levels in experimental DVT [95]. Although the complement system can increase extracellular ROS through the activation of neutrophils [96], the predominant inflammatory cell type present in the forming thrombus, little work has been afforded to the involvement of ROS in complement-mediated DVT-promoting processes.

\section{ROS and Calcium Homeostasis}

Calcium is an essential component of the human diet and is required for the activity of many enzymes, including those involved in processes related to DVT. Many of these calcium-based signaling systems interact with redox signaling pathways. These interactions are bidirectional, with calcium channels on plasma and organellar membranes regulated by oxidative modifications [97-100], and with ROS generators such as NOX enzymes regulated by calcium [101-103]. Although this interplay has been documented in many different cell types and a similar regulation is likely to take place in DVT, it has to be noted that studies in DVT models are lacking.

Platelet activation, for instance, relies on cytoplasmic calcium surges. These calcium surges occur mainly through store-operated calcium entry (SOCE), where calcium is first released from intracellular stores, followed by entry through the plasma membrane. In SOCE, the initial calcium release from intracellular stores is mediated by the stromal interaction molecule 1 (STIM1) protein, while the following calcium influx from the extracellular space is mediated by the plasma membrane channel Orai1 [104]. Both of these key proteins are under redox control. STIM1 disulfide formation decreases calcium influx [97], while S-glutathionylation of STIM1 leads to Orai1 activation, independent of calcium release from stores [98]. Another calcium channel through which calcium enters platelets from the extracellular space is the transient receptor potential channel 6 (TRPC6) [104]. Not observed in platelets but seen in kidney cells [99] as well as B lymphoma cells [100], TRPC6 was found to directly interact with plasma membrane NOX2, with ROS generated from this NOX2 exerting a positive feedback loop on TRPC6 activity.

STIM1, Orai1 and TRPC6 are also involved in angiogenesis, a process important for thrombus resolution, as outlined later in this article [105].

Calcium-ROS interplay is also important for processes by which leukocytes might contribute to DVT formation. In neutrophils, for instance, NOX2 is essential for neutrophils' role in DVT formation. Activation of this enzyme in neutrophils relies on a calcium signaling pathway [103]. In mast cells, ROS activates redox-sensitive calcium channels that facilitate the rise in cytoplasmic calcium needed for MC degranulation [93]. 


\section{Venous Thrombus Resolution}

It is well known that rapid natural thrombus resolution is associated with improved long-term outcome [2]. Current treatment options for rapid thrombus removal by thrombolysis with or without mechanical means have, however, significant hemorrhagic side effects and are therefore only deployed in severe cases in which immediate vessel recanalization is required [3]. A better understanding of the processes that enhance natural resolution might give rise to novel therapies that would especially benefit DVT patients with long-term complications such as recurrent VTE, post-thrombotic syndrome or chronic thromboembolic pulmonary hypertension (CTEPH).

Venous Thrombus resolution is a process of tissue organization and remodeling that resembles the processes that take place during normal wound healing. It requires the concerted action of the following processes: fibrinolysis; proteolysis; inflammation; and angiogenesis. In the early stage of resolution, a gradual process of remodeling replaces the fragile erythrocyte- and fibrin-rich matrix of the thrombus with collagen and other extracellular matrix proteins [26]. Angiogenic stimuli, including the production of vascular endothelial growth factor within the thrombus, promote the formation of neovascular channels within the thrombus [19]. Leukocytes are important mediators of these processes, with neutrophils predominating in the early, and monocytes in the late, stages of thrombus resolution. Each of these processes can be modulated by ROS (Figure 3).

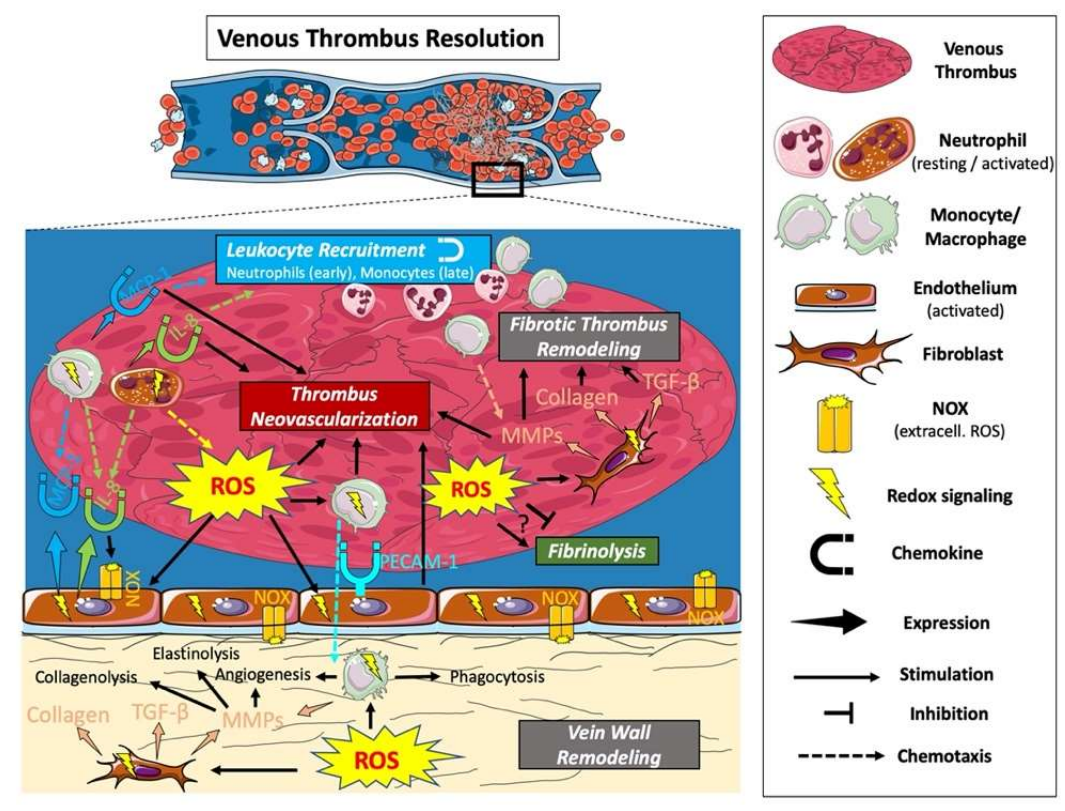

Figure 3. The role of ROS in the resolution of a venous thrombus. Oxidative stress at the site of a venous thrombus (intra- and abluminal) leads to the recruitment of leukocytes (with neutrophils predominating in the early, and monocytes predominating in the later phase of resolution) and fibroblasts. ROS-mediated cell recruitment results from direct chemotactic effects, or indirectly through increased expression of chemokines and adhesion molecules. The recruited cells promote thrombus resolution through phagocytic action removing red cell mass, thrombus and vein wall remodeling including fibrin degradation and the stimulation of new ECM deposition and neovessel formation. There are conflicting reports on whether fibrinolysis is stimulated or inhibited by ROS.

\section{ROS and Fibrinolysis}

Tissue-type and urokinase-type plasminogen activators (tPA and uPA) are found within mononuclear cells that accumulate in experimental venous thrombi $[106,107]$. It appears, however, that only uPA activity is the main determinant of thrombus resolution and that this is associated with the accumulation of cells derived from the bone marrow, possibly monocytes [108,109]. Deficiency in either of the two plasminogen activator inhibitors, PAI-1 and PAI-2, results in enhanced resolution [110]. 
ROS are intimately involved in the regulation of the fibrinolytic system. Early in vitro studies have shown that oxidation reduces the ability of fibrinogen to activate tPA [39] and that expression of PAI-1 in endothelial cells [111], VSMCs [112] and other cells [113] is dependent on ROS. PAI-1 inhibits uPA in addition to tPA and ROS-dependent downregulation of PAI-1, which could thereby influence the resolution process. NOX enzymes seem to be an important source of the ROS involved in this process $[112,114]$. The signaling processes involved in PAI-1 upregulation involves the redox-controlled transcription factor AP-1 upon oxidative stress and insulin stimulation [115], whereas hypoxia-inducible factor 1 (HIF-1) is involved upon thrombin stimulation [112]. In line with the ROS-dependent regulation of PAI-1, the antioxidant Vitamin E has been shown to improve fibrinolytic function by reducing PAI-1 activity in patients with coronary spastic angina, associated with a decrease in oxidative stress [116].

There are, however, conflicting reports showing that ROS are capable of stimulating fibrinolysis by inactivating PAI in vitro [117] and may prevent hypoxia-mediated PAI upregulation [118]. Later experimental in vivo studies also show that, while PAI expression can be upregulated by ROS in adipose tissues [119] and in hyperoxia-induced oxidative stress in the lung [120], PAI levels may be increased in hepatocytes in the face of reduced ROS activity caused by overexpression of the antioxidant enzyme GPX [121].

The fibrinolytic system can be modulated by ROS in a variety of ways. The conflicting observations regarding the direction of this modulation imply a complex regulation that is dependent on the cell type, stimulus and whether ROS mediate their effects as part of specific second messengers or as part of unspecific oxidative stress.

\section{ROS and Leukocyte Recruitment}

Venous thrombi are quickly invaded by circulating leukocytes, and animal models have shown that thrombus resolution is impaired when the early neutrophil [122] or late monocyte [108,123] invasion is restricted. Resolution, on the other hand, is enhanced when monocyte numbers are increased [123]. Leukocyte recruitment is mediated by a variety of processes, all of which can be modulated by ROS.

ROS can directly act as chemoattractants for neutrophils in vitro and in vivo [124,125] and neutrophil chemotaxis can be inhibited by increased circulating presence of the antioxidant enzyme TRX [126]. Cell culture supplementation with different ROS also results in increased leukocyte adhesion molecule expression and leukocyte endothelial adhesion [127]. Cell adhesion molecules (CAMs), in particular platelet-endothelial CAM-1 (PECAM-1), are important for leukocyte thrombus invasion. The thrombi of PECAM-1 knockout mice have an impaired resolution and contain fewer macrophages in an IVC ligation model [128]. PECAM-1 is also downregulated in plasma of patients with non-resolving DVT and within unresolved thrombi of chronic thromboembolic pulmonary hypertension (CTEPH) patients [128]. Oxidative stress induces transendothelial migration of monocytes via phosphorylation of PECAM-1 in vitro [129], while PECAM-1 also downregulates the antioxidant enzyme heme-oxygenase-1 (HO-1) via the master antioxidant transcription factor Nrf2 and modifies intracellular ROS levels in human endothelial cells [130].

IL-8 is a chemokine produced by endothelial cells, monocytes and neutrophils, and it recruits neutrophils and, to a lesser extent, monocytes. Increased circulating levels of IL-8 are associated with an increased risk of recurrent DVT [131], while increased levels are associated with increased thrombus resolution in an experimental in vivo model [132]. Patients with chronic granulomatous disease (CGD) have gene mutations that give rise to impaired NOX function. Neutrophils isolated from CGD patients produce 2- to 4-fold more IL-8 and show a sustained IL-8 mRNA response after fMLP stimulation compared with normal neutrophils, while normal neutrophils treated with an ROS scavenger or NOX inhibitor have similar IL-8 responses to CGD neutrophils. Taken together, these data suggest that NOX activity reduces neutrophil IL-8 production [133]. In line with this, exposure of mouse neutrophils to extracellular $\mathrm{H}_{2} \mathrm{O}_{2}$ potently inhibits nuclear translocation of NF- $\mathrm{kB}$, which induces the expression of proinflammatory cytokines such as IL-8, suggesting that extracellular oxidative stress reduces IL-8 production [134]. Contrary to expectations, ROS scavengers were shown to decrease the production 
of IL-8 in LPS- [135] and IgE-mediated [136] human neutrophil activation. A recent study in human neutrophils hinted at a more complex involvement of NOX. While intracellular IL-8 levels of fMLP stimulated neutrophils are increased upon NOX inhibition, extracellular release of IL-8 is reduced under the same condition, suggesting interference in the release mechanism [137]. The conflicting evidence of ROS involvement in neutrophil IL-8 regulation may result from differences in and off-target effects of neutrophil activators and ROS inhibitors. The effects of ROS on IL-8 regulation also vary according to cell type. In macrophages, for example, extracellular oxidative stress has no effect on cytokine production [134], while in human umbilical vein endothelial cells (HUVECs), exogenous superoxide upregulates IL-8 mRNA expression [32]. Besides being regulated by ROS, IL-8 induces ROS production in endothelial cells via NOX1 [138]. To what degree ROS-mediated IL-8 chemotaxis is important to leukocyte recruitment in thrombus formation (detrimental) or leukocyte recruitment in thrombus resolution (beneficial) remains to be studied.

Monocyte chemotactic protein-1 (MCP-1) is expressed by various vascular cells such as endothelial cells, VSMCs, fibroblasts, monocytes and macrophages [139]. MCP-1 mediates monocyte recruitment into the thrombus and administration of MCP-1 accelerates the organization and resolution of venous thrombi $[123,140]$. Although the influence of ROS on MCP-1 regulation has yet to be studied in thrombosis models, functional MCP-1 studies hint at a possible redox regulation. MCP-1 expression in human endothelial cells stimulated by IL-4 reveals the involvement of intracellular ROS, most likely generated by NOX enzymes [141]. Similar results were obtained in retinal endothelial cells exposed to ischemia [142] and in hepatic stellate cells upon alcoholic liver injury [143]. Besides this potential involvement of ROS as messengers in intracellular ROS signaling, experiments with ox-LDL, a marker of extracellular oxidative stress, have shown the upregulation of MCP-1 in endothelial cells and VSMCs [144].

\section{ROS and Thrombus Neovascularization}

Angiogenic stimuli drive the formation of neovascular channels within the thrombus and vessel wall during resolution. The importance of this process for resolution is evident from studies that have shown that overexpression and inhibition of the most potent angiogenic factor, VEGF, enhances and impairs thrombus resolution, respectively $[145,146]$. It has become clear that thrombus neovascularization also depends on leukocyte recruitment, with monocytes being one of the most important effector cells in this process [147]. It is therefore not surprising that the molecules involved in leukocyte-attraction PECAM-1, IL-8, MCP-1 also have proangiogenic activity $[128,132,145,148]$, all of which we have described as being modulated by ROS.

Within a newly formed venous thrombus, $\mathrm{pO}_{2}$ levels are only $10 \%$ of that in circulating venous blood. This relative hypoxia is associated with increased levels of HIF-1 and angiogenic factors within the thrombus [89]. Hypoxia is also a prime activator of ROS and there is extensive evidence for a proangiogenic role for extracellular oxidative stress and intracellular, NOX-dependent redox signaling [149]. The main mechanism of oxidative stress-induced angiogenesis involves HIF-1/VEGF signaling, but VEGF-independent mechanisms, such as the ones mediated by lipid oxidation products and the downstream TLR2/MyD88 pathway, have also been reported $[149,150]$. The extracellular chaperone glypican-1 protects VEGF from oxidative damage, highlighting the role of angiogenesis in oxidative environments [151]. Thrombin, for instance, was shown to activate the HIF-1 signaling pathway and to increase VEGF expression in VSMCs [112]. Thrombin-stimulated in vitro angiogenesis is diminished by NOX2 or NOX5 knockdown in endothelial cells [152]. Consistent with this, several antioxidants, such as NOX inhibitors, free radical scavengers and overexpression of antioxidant enzymes, inhibit angiogenesis [153-155].

\section{ROS and Fibrotic Thrombus Remodeling}

The purpose of thrombus resolution is to restore lumen patency and, hence, vessel function. The exacerbation or impairment of mechanisms within this 'intravascular wound healing' process can lead 
to chronic, fibrotic thrombi and vein walls, causing persistent impediment to blood flow and vessel dysfunction, respectively.

During the early resolution process, the fragile erythrocyte- and fibrin-rich thrombus is replaced by collagen and, depending on the balance between profibrotic signals and degradative protease activity, the thrombus and vein wall may become fibrotic, as evidenced by the association seen between impaired thrombus resolution and elevated collagen deposition [122,128]. Leukocytes, vascular smooth muscle cells (VSMCs), and myofibroblasts together with the expression of profibrotic factors such as TGF- $\beta$ within the thrombus and the adjacent vein wall, are key drivers of the remodeling in these structures [147].

TGF- $\beta 1$-mediated fibroblast activation and the subsequent fibrotic response was shown to depend on NOX4-derived ROS in the lung [156]. Consistent with this, NOX4 knockout mice have defects in TGF- $\beta 1$ signaling in a lung fibrosis model [157]. The involvement of NOX enzymes in TGF- $\beta 1$ signaling has furthermore been reported in human pulmonary artery smooth muscle cells [158], cardiac fibroblasts [159] and dermal fibroblasts [160]. In contrast to this, NOX4 deficiency did not affect myofibroblast formation but nonetheless decreased collagen deposition in a mouse model of wound repair [161]. Thrombus and vascular wall remodeling are of particular importance in the pulmonary arteries, as long-term complications of pulmonary embolisms (PE) such as CTEPH are associated with high morbidity and mortality. A recent in vivo study has shown that pulmonary arterial (PA) endothelial dysfunction, induced by NOX-derived ROS, is an early event upon repetitive PE with sustained elevation of PA pressure [162]. VSMC proliferation is an important component of vascular remodeling, particularly important for the long-term patency of vein grafts. PAR2 receptors, for instance, mediate coagulation-independent actions of activated factor $\mathrm{X}$ (FXa), such as the proliferation of VSMCs. The intracellular signaling pathway of this process has been shown to involve NOX1-derived ROS in vitro [163].

These profibrotic mechanisms are counteracted by processes that drive the degradation of the ECM. Elastinolysis is believed to occur early and to be responsible for increased vein wall stiffness during the resolution process [164]. Similarly, collagenolysis seems to occur within the first seven days of thrombus formation in a murine model [165]. MMP-2 and MMP-9 are suggested to be the most important enzymes in this process as they not only have protein degradative properties, but also facilitate monocyte invasion, neovascularization and regulate plasminogen activation, as well as a number of growth factor pathways [166-170]. Deletion of MMP-9 is associated with decreased vein wall fibrosis in experimental stasis DVT, likely directed by monocytes [171]. Similarly, deletion of the CCR2 receptor impairs thrombus resolution, associated with a reduction in MMP-2 and MMP-9 [172].

There is extensive evidence to suggest that ROS modulate both MMP gene expression and MMP activation [173]. Extracellular ROS were shown to increase expression of various MMPs in vitro, including MMP-2 and MMP-9 in endothelial cells and macrophage-derived foam cells [174-176], with ROS derived from NOX enzymes, xanthine oxidase and mitochondria responsible for MMP-1 and MMP-9 generation $[177,178]$. Pharmacological antioxidants $[178,179]$ or genetically overexpressed antioxidant enzymes [180] have the opposite effect. Intracellular signaling pathways important for MMPs and their endogenous inhibitors (TIMPs), such as Ras and MAPK, are also modulated by ROS through oxidative phosphatase inactivation [181]. Integrin ligand-binding is one of the most important activation mechanisms of MMPs and is dependent on ROS derived from NOX enzymes, 5-lipoxygenase and mitochondrial release [181].

\section{Diseases with Increased Risk of DVT and Involving ROS}

A number of conditions increase the risk for DVT and the mechanisms regulating many of these have been identified to involve dysregulated ROS levels. An example of this is Antiphospholipid Syndrome (APS). Venous and arterial thrombi are major manifestations of this condition and endosomal redox signaling has been identified as an important pathophysiological mechanism driving thrombus formation [182]. The formation of venous thrombi is inhibited, for example, in a mouse NOX2 knockout 
APS model [183]. APS patients with thrombosis also carry higher circulating levels of reduced Factor XI (FXI), one of the constituents of the coagulation cascade [184]. This reduced form of FXI is generated by the action of oxidoreductases (TRX-1) and is more easily activated by thrombin than the oxidized form, giving a more procoagulant state in APS patients [184]. Hydroxychloroquine (HCQ), which has been used to treat patients with APS, inhibits proinflammatory signaling pathways by targeting endosomal NOX, further supporting an important role for ROS in APS [185].

Behçet's disease is another autoimmune disorder with an increased risk for developing venous thrombosis. A recent study of 98 Behçet's disease patients has shown that thrombus formation was promoted by oxidatively altered fibrinogen, which was associated with neutrophil activation and enhanced NOX-dependent ROS production [186].

Increased risk of DVT has also been reported for exposure to air pollution [187] and a recent study suggests that this might be mediated by increased oxidative stress [188]. Endothelial cells exposed to ultrafine particles show upregulated TF expression via NOX4 signaling, earlier thrombin generation and faster fibrin clot formation [188]. The implications of this finding in vivo remain to be explored.

Oxidative stress is associated with conditions that result from lifestyles common in western countries. One of these is Metabolic Syndrome, which is positively associated with the risk of venous thrombosis [189]. The oxidative stress in these patients leads to substantially elevated levels of oxidized low-density lipoproteins (ox-LDL), which is known to trigger platelet activation and be causally involved in prothrombotic mechanisms [52]. Ox-LDL binds to CD36 on platelets and induces their activation via NOX2 induction [190]. In line with this, the plasma of obese women contains elevated levels of the platelet activation markers soluble CD40L (sCD40L) and soluble P-selectin, associated with NOX2 upregulation in platelets [53].

Chronic stress is another lifestyle factor that is positively associated with ROS levels [191]. Chronic stress is associated with increased oxidative stress, platelet activation and DVT formation in an experimental model, an effect that was alleviated by antioxidant treatment [192]. ROS formation following chronic stress in another experimental model, synergistically increased by NOX enzymes through the renin-angiotensin system, and inflammatory reactions in white adipose tissue, resulted in a prothrombotic state [193].

DVT rates increase with age and this is thought to involve oxidative stress as aging-related venous thrombosis in mice is promoted by the redox sensor, mTORC1, via the elevation of platelet reactivity, an effect that is reduced by antioxidant therapy with NAC [194]. NAC had no beneficial effect in young mice, however, suggesting that antioxidant treatment is only effective when levels of oxidative stress are high (as is present in older mice), while the lower oxidative stress and smaller thrombus size present in younger mice is not amenable to significant treatment effects [194].

Age-related prothrombotic effects also involve the down-regulation of the protective NO pathway and upregulation of the NOX- and COXs-dependent oxidative stress pathway, promoting TF expression and activity in endothelial cells [8]. Age-dependent increased susceptibility to venous thrombosis is rescued by overexpression of the antioxidant enzyme GPX-1 [67].

\section{Dietary and Pharmacological Antioxidants}

\subsection{Dietary}

Various nutritional factors and drugs are known to have antioxidant functions. While evidence exists that they influence various distinct processes important for DVT formation, their overall effect on DVT has yet to be established. The antioxidant effects of vitamins A, C and E for instance are well known [18]. Vitamin E reduces cardiovascular events in subgroups of patients with increased oxidative stress [195], but supplementation in the general population holds no cardiovascular benefit, and may even increase all-cause mortality [196]. Data on how vitamin E might influence the formation and/or resolution of DVT are sparse and limited to two components of the DVT formation process, platelet activation and the coagulation cascade. Activation of isolated platelets with collagen can be 
inhibited by the antioxidative effects of vitamin E [65]. Vitamin E downregulates the in vitro expression of the initiating protein of the coagulation cascade, TF, in monocytes, suggestive of an anticoagulant function $[197,198]$.

In hemodialysis, the extracorporeal circuit leads to activation of the clotting cascade, which is associated with increased ROS generation and reduced antioxidant mechanisms [199]. The use of a less thrombogenic ethylene-vinyl-alcohol (EVAL) dialysis membrane inhibits NOX2-mediated ROS production, and the use of other materials with ROS-scavenging activities results in the reduced activation of clotting $[200,201]$. The administration of natural antioxidants, such as red grape juice, which has antioxidant properties, reduces neutrophil NOX activity and plasma concentrations of oxidized LDL (ox-LDL) to an even greater extent than vitamin $\mathrm{E}$ in patients undergoing hemodialysis [199].

Beer contains a nutritional antioxidant, xanthohumol, for which a direct beneficial effect for the development of DVT has been shown. Xanthohumol, present in hops that are used in beer making, prevents both arterial and venous thrombosis in mice by decreasing ROS accumulation and inhibiting platelet activation without increased bleeding risk [202]. Moderate beer consumption is associated with a decreased risk of venous thrombosis [202-204]. Red wine inhibits platelet activation and diminishes experimental venous thrombosis in rats, an effect that was associated with a substantial increase in total radical-trapping antioxidant parameters (TRAP) [205]. Antioxidant polyphenols, present in a variety of foods and drinks, including red wine and chocolate, are known to reduce platelet reactivity [206] and this is believed to be one of the major drivers of improved cardiovascular mortality when wine is moderately consumed [207]. The Mediterranean diet, and olive oil in particular, also favor antioxidant mechanisms. A cross-over study comparing olive oil with corn oil revealed olive oil intake caused a reduced post-prandial ROS increase in serum and platelets via NOX2 downregulation [208]. It appears, therefore, that nutritional antioxidants can modulate several important steps in the DVT formation process, but their overall benefit in reducing this condition remains to be established.

\subsection{Pharmaceutical}

The beneficial effects of statins in cardiovascular disease are mainly attributed to their lipid lowering effects, but there is extensive evidence to suggest that they have pleiotropic effects in regulating disease. Statins decrease oxidative stress and platelet activation in hypercholesterolemic patients by an early and late mechanism. The early effect is dependent on the direct inhibition of platelet NOX2 and independent of any lipid lowering effect, while the late effect is associated with LDL lowering including the platelet-activating molecule, ox-LDL $[209,210]$. These antiplatelet effects could be responsible for the reduction in thrombotic events observed upon pre-procedural statin therapy [211]. The resolution in venous thrombi is also enhanced by statin therapy, although the mechanism has yet to be reported [212]. Antiplatelets (aspirin) and anticoagulants (Xa inhibitor, rivaroxaban) also have antioxidant properties, as they reduce NOX2-mediated platelet ROS production [213,214].

Most of these drugs have already been evaluated for their benefit in DVT patients, but there are also other antioxidant drugs that are used in other fields of medicine. Modified versions and dosages of these drugs could be repurposed for use in thrombotic diseases. Thioredoxin (TRX) inhibitors, for example, are currently under investigation in clinical trials for diseases involving an imbalance in the NADPH/thioredoxin reductase/thioredoxin system, such as cancer. TRX inhibitors also attenuate platelet function and thrombus formation, which could lead to their being repurposed as antiplatelet agents [215]. The oral anti-diabetic drug, Alogliptin, diminishes oxidative stress and the associated prothrombotic state in a mouse model of chronic stress [193].

Drugs with pro-oxidant properties, such as the anticancer, estrogen-receptor-blocker tamoxifen, might negatively impact processes related to DVT. Platelet activation through tamoxifen-mediated NOX upregulation has previously been suggested to be causally involved in the increased risk of venous thrombosis in breast cancer patients treated with tamoxifen [216]. 


\section{Conclusions}

ROS are involved in the regulation of all of the major processes that promote the formation of venous thrombi. These include coagulation; platelet reactivity; and sterile inflammation (for example NETosis) during formation. Oxidative stress also appears to favor the 'intravascular wound healing' processes that control the remodeling of a venous thrombus and adjacent vein wall including fibrinolysis; sterile inflammation (monocyte accumulation); extracellular matrix deposition and its remodeling; and neovascularization.

Dysregulated redox control is a common feature of conditions with an elevated risk of venous thrombosis, and therefore restoring oxidative balance might represent a possible therapeutic option in some of these patients. However, the ubiquitous deployment of ROS in the regulation of both physiological and pathophysiological redox regulatory mechanisms poses challenges in determining which redox pathways can be targeted for therapeutic benefit without affecting normal hemostasis.

Funding: C.G. is funded by a British Heart Foundation (BHF) PhD studentship (FS/18/60/34181).

Acknowledgments: All figures were created with elements from Servier Medical Art [217].

Conflicts of Interest: The authors declare no conflict of interest.

$\begin{array}{ll}\text { Abbreviations } \\ \text { AP-1 } & \text { Activator protein 1 } \\ \text { APC } & \text { Activated protein C } \\ \text { APS } & \text { Antiphospholipid Syndrome } \\ \text { ATIII } & \text { Antithrombin III } \\ \text { AQP } & \text { Aquaporin channel } \\ \text { CAM } & \text { Cell adhesion molecule } \\ \text { CCR2 } & \text { C-C chemokine receptor type 2 } \\ \text { CGD } & \text { X-linked chronic granulomatous disease } \\ \text { COX } & \text { Cyclooxygenase } \\ \text { CVD } & \text { Cardiovascular disease } \\ \text { CAM } & \text { Cell adhesion molecule } \\ \text { CTEPH } & \text { Chronic thromboembolic pulmonary hypertension } \\ \text { DVT } & \text { Deep vein thrombosis } \\ \text { ECM } & \text { Extracellular matrix } \\ \text { EVAL } & \text { Ethylene-vinyl-alcohol } \\ \text { fMLP } & \text { N-formyl-met-leu-phe } \\ \text { FX } & \text { Factor X } \\ \text { FXI } & \text { Factor XI } \\ \text { GPVI } & \text { Glycoprotein VI } \\ \text { GPX } & \text { Glutathione peroxidase } \\ \text { Hb } & \text { Hemoglobin } \\ \text { HCQ } & \text { Hydroxychloroquine } \\ \text { HIF } & \text { Hypoxia-inducible factor } \\ \text { HO } & \text { Heme oxygenase } \\ \text { HUVEC } & \text { Human umbilical vein endothelial cell } \\ \text { IgE } & \text { Immunoglobulin E } \\ \text { IL-8 } & \text { Interleukin-8 } \\ \text { IVC } & \text { Inferior vena cava } \\ \text { LPS } & \text { Lipopolysaccharide } \\ \text { MAPK } & \text { Mitogen-activated protein kinase } \\ \text { MC } & \text { Mast cell } \\ \text { MCP-1 } & \text { Monocyte chemotactic protein 1 } \\ \text { MMP } & \text { Matrix metalloproteinase } \\ & \end{array}$




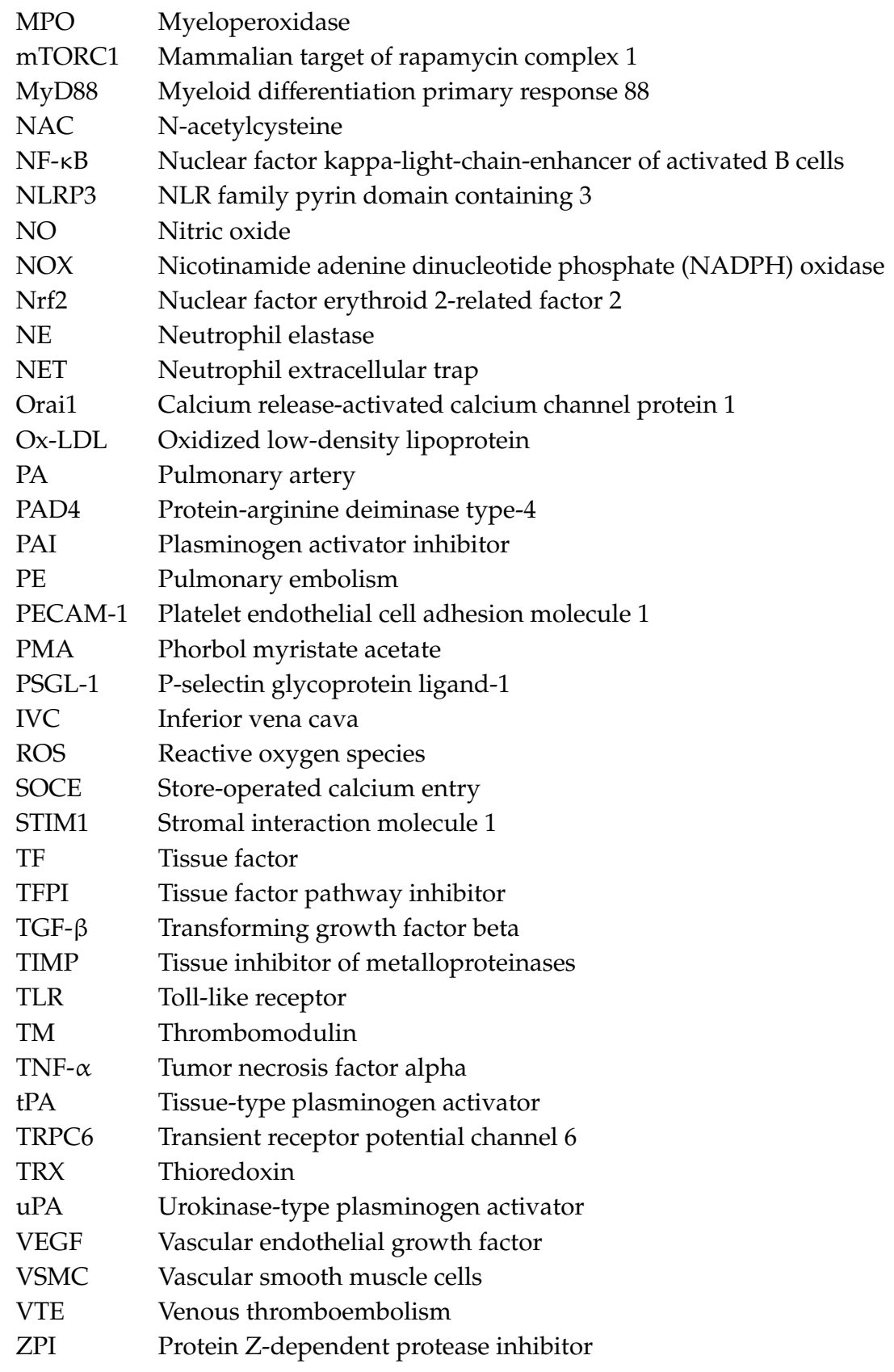

\section{References}

1. Raskob, G.E.; Angchaisuksiri, P.; Blanco, A.N.; Buller, H.; Gallus, A.; Hunt, B.J.; Hylek, E.M.; Kakkar, A.; Konstantinides, S.V.; McCumber, M.; et al. Thrombosis: A major contributor to the global disease burden. J. Thromb. Haemost. 2014, 12, 1580-1590. [CrossRef] [PubMed]

2. Saarinen, J.; Kallio, T.; Lehto, M.; Hiltunen, S.; Sisto, T. The occurrence of the post-thrombotic changes after an acute deep venous thrombosis. A prospective two-year follow-up study. J. Cardiovasc. Surg. 2000, 41, 441-446.

3. Patterson, B.O.; Hinchliffe, R.; Loftus, I.M.; Thompson, M.M.; Holt, P.J.E. Indications for catheter-directed thrombolysis in the management of acute proximal deep venous thrombosis. Arterioscler. Thromb. Vasc. Biol. 2010, 30, 669-674. [CrossRef] [PubMed]

4. Reichmann, D.; Voth, W.; Jakob, U. Maintaining a healthy proteome during oxidative stress. Mol. Cell 2018, 69, 203-213. [CrossRef]

5. Murphy, M.P. How mitochondria produce reactive oxygen species. Biochem. J. 2009, 417, 1-13. [CrossRef] 
6. Tu, B.P.; Weissman, J.S. The FAD-and O(2)-dependent reaction cycle of Ero1-mediated oxidative protein folding in the endoplasmic reticulum. Mol. Cell 2002, 10, 983-994. [CrossRef]

7. Hrycay, E.G.; Bandiera, S.M. Involvement of cytochrome P450 in reactive oxygen species formation and cancer. In Advances in Pharmacology (San Diego, Calif.); Academic Press: Cambridge, MA, USA, 2015; Volume 74.

8. Silva, G.C.; Abbas, M.; Khemais-Benkhiat, S.; Burban, M.; Ribeiro, T.P.; Toti, F.; Idris-Khodja, N.; Côrtes, S.F.; Schini-Kerth, V.B. Replicative senescence promotes prothrombotic responses in endothelial cells: Role of NADPH oxidase-and cyclooxygenase-derived oxidative stress. Exp. Gerontol. 2017, 93, 7-15. [CrossRef]

9. Mashima, R.; Okuyama, T. The role of lipoxygenases in pathophysiology; new insights and future perspectives. Redox Biol. 2015, 6, 297-310. [CrossRef]

10. Panday, A.; Sahoo, M.K.; Osorio, D.; Batra, S. NADPH oxidases: An overview from structure to innate immunity-associated pathologies. Cell. Mol. Immunol. 2015, 12, 5-23. [CrossRef]

11. Enami, S.; Sakamoto, Y.; Colussi, A.J. Fenton chemistry at aqueous interfaces. Proc. Natl. Acad. Sci. USA 2014, 111, 623-628. [CrossRef]

12. Muller, F.L.; Song, W.; Liu, Y.; Chaudhuri, A.; Pieke-Dahl, S.; Strong, R.; Huang, T.-T.; Epstein, C.J.; Roberts, L.J.; Csete, M.; et al. Absence of CuZn superoxide dismutase leads to elevated oxidative stress and acceleration of age-dependent skeletal muscle atrophy. Free Radic. Biol. Med. 2006, 40, 1993-2004. [CrossRef] [PubMed]

13. Cao, C.; Leng, Y.; Kufe, D. Catalase activity is regulated by c-Abl and Arg in the oxidative stress response. J. Biol. Chem. 2003, 278, 29667-29675. [CrossRef] [PubMed]

14. Brigelius-Flohé, R.; Maiorino, M. Glutathione peroxidases. Biochim. Biophys. Acta Gen. Subj. 2013, 1830, 3289-3303. [CrossRef] [PubMed]

15. Duvigneau, J.C.; Esterbauer, H.; Kozlov, A.V. Role of heme oxygenase as a modulator of heme-mediated pathways. Antioxidants 2019, 8, 475. [CrossRef] [PubMed]

16. Lu, J.; Holmgren, A. The thioredoxin antioxidant system. Free Radic. Biol. Med. 2014, 66, 75-87. [CrossRef] [PubMed]

17. Forman, H.J.; Zhang, H.; Rinna, A. Glutathione: Overview of its protective roles, measurement, and biosynthesis. Mol. Asp. Med. 2009, 30,1-12. [CrossRef]

18. He, L.; He, T.; Farrar, S.; Ji, L.; Liu, T.; Ma, X. Antioxidants maintain cellular redox homeostasis by elimination of reactive oxygen species. Cell. Physiol. Biochem. 2017, 44, 532-553. [CrossRef]

19. Modarai, B.; Guiver Burnand, K.; Humphries, J.; Waltham, M.; Smith, A. The role of neovascularisation in the resolution of venous thrombus. Thromb. Haemost. 2005, 93, 801-809. [CrossRef]

20. Brooks, E.G.; Trotman, W.; Wadsworth, M.P.; Taatjes, D.J.; Evans, M.F.; Ittleman, F.P.; Callas, P.W.; Esmon, C.T.; Bovill, E.G. Valves of the deep venous system: An overlooked risk factor. Blood 2009, 114, 1276-1279. [CrossRef]

21. Stewart, G.J.; Ritchie, W.G.; Lynch, P.R. Venous endothelial damage produced by massive sticking and emigration of leukocytes. Am. J. Pathol. 1974, 74, 507-532.

22. Fuchs, T.A.; Brill, A.; Duerschmied, D.; Schatzberg, D.; Monestier, M.; Myers, D.D.; Wrobleski, S.K.; Wakefield, T.W.; Hartwig, J.H.; Wagner, D.D. Extracellular DNA traps promote thrombosis. Proc. Natl. Acad. Sci. USA 2010, 107, 15880-15885. [CrossRef] [PubMed]

23. Gupta, A.K.; Joshi, M.B.; Philippova, M.; Erne, P.; Hasler, P.; Hahn, S.; Resink, T.J. Activated endothelial cells induce neutrophil extracellular traps and are susceptible to NETosis-mediated cell death. FEBS Lett. 2010, 584, 3193-3197. [CrossRef]

24. Day, S.M.; Reeve, J.L.; Pedersen, B.; Farris, D.M.; Myers, D.D.; Im, M.; Wakefield, T.W.; Mackman, N.; Fay, W.P. Macrovascular thrombosis is driven by tissue factor derived primarily from the blood vessel wall. Blood 2005, 105, 192-198. [CrossRef] [PubMed]

25. Iacoviello, L.; Kolpakov, V.; Salvatore, L.; Amore, C.; Pintucci, G.; De Gaetano, G.; Donati, M.B. Human endothelial cell damage by neutrophil-derived cathepsin G. Role of cytoskeleton rearrangement and matrix-bound plasminogen activator inhibitor-1. Arterioscler. Thromb. Vasc. Biol. 1995, 15, 2037-2046. [CrossRef] [PubMed]

26. Saha, P.; Humphries, J.; Modarai, B.; Mattock, K.; Waltham, M.; Evans, C.E.; Ahmad, A.; Patel, A.S.; Premaratne, S.; Lyons, O.T.A.; et al. Leukocytes and the natural history of deep vein thrombosis. Arterioscler. Thromb. Vasc. Biol. 2011, 31, 506-512. [CrossRef] [PubMed]

27. Ponomaryov, T.; Payne, H.; Fabritz, L.; Wagner, D.D.; Brill, A. Mast cells granular contents are crucial for deep vein thrombosis in mice. Circ. Res. 2017, 121, 941-950. [CrossRef] 
28. Budnik, I.; Brill, A. Immune factors in deep vein thrombosis initiation. Trends Immunol. 2018, 39, 610-623. [CrossRef]

29. Golino, P.; Ragni, M.; Cirillo, P.; Avvedimento, V.E.; Feliciello, A.; Esposito, N.; Scognamiglio, A.; Trimarco, B.; Iaccarino, G.; Condorelli, M.; et al. Effects of tissue factor induced by oxygen free radicals on coronary flow during reperfusion. Nat. Med. 1996, 2, 35-40. [CrossRef]

30. Cadroy, Y.; Dupouy, D.; Boneu, B.; Plaisancié, H. Polymorphonuclear leukocytes modulate tissue factor production by mononuclear cells: Role of reactive oxygen species. J. Immunol. 2000, 164, 3822-3828. [CrossRef]

31. Herkert, O.; Diebold, I.; Brandes, R.P.; Hess, J.; Busse, R.; Görlach, A. NADPH oxidase mediates tissue factor-dependent surface procoagulant activity by thrombin in human vascular smooth muscle cells. Circulation 2002, 105, 2030-2036. [CrossRef]

32. Jacobi, J.; Kristal, B.; Chezar, J.; Shaul, S.M.; Sela, S. Exogenous superoxide mediates pro-oxidative, proinflammatory, and procoagulatory changes in primary endothelial cell cultures. Free Radic. Biol. Med. 2005, 39, 1238-1248. [CrossRef] [PubMed]

33. Banfi, C.; Brioschi, M.; Barbieri, S.S.; Eligini, S.; Barcella, S.; Tremoli, E.; Colli, s.; Mussoni, L. Mitochondrial reactive oxygen species: A common pathway for PAR1-and PAR2-mediated tissue factor induction in human endothelial cells. J. Thromb. Haemost. 2009, 7, 206-216. [CrossRef] [PubMed]

34. Djordjevic, T.; Pogrebniak, A.; BelAiba, R.S.; Bonello, S.; Wotzlaw, C.; Acker, H.; Hess, J.; Görlach, A. The expression of the NADPH oxidase subunit $\mathrm{p} 22$ phox is regulated by a redox-sensitive pathway in endothelial cells. Free Radic. Biol. Med. 2005, 38, 616-630. [CrossRef] [PubMed]

35. Ohkura, N.; Hiraishi, S.; Itabe, H.; Hamuro, T.; Kamikubo, Y.; Takano, T.; Matsuda, J.; Horie, S. Oxidized phospholipids in oxidized low-density lipoprotein reduce the activity of tissue factor pathway inhibitor through association with its carboxy-terminal region. Antioxid. Redox Signal. 2004, 6, 705-712. [CrossRef] [PubMed]

36. Nalian, A.; Iakhiaev, A.V. Possible mechanisms contributing to oxidative inactivation of activated protein C: Molecular dynamics study. Thromb. Haemost. 2008, 100, 18-25. [CrossRef]

37. Glaser, C.B.; Morser, J.; Clarke, J.H.; Blasko, E.; McLean, K.; Kuhn, I.; Chang, R.J.; Lin, J.H.; Vilander, L.; Andrews, W.H.; et al. Oxidation of a specific methionine in thrombomodulin by activated neutrophil products blocks cofactor activity. A potential rapid mechanism for modulation of coagulation. J. Clin. Investig. 1992, 90, 2565-2573. [CrossRef]

38. Dayal, S.; Gu, S.X.; Hutchins, R.D.; Wilson, K.M.; Wang, Y.; Fu, X.; Lentz, S.R. Deficiency of superoxide dismutase impairs protein $\mathrm{C}$ activation and enhances susceptibility to experimental thrombosis. Arterioscler. Thromb. Vasc. Biol. 2015, 35, 1798-1804. [CrossRef]

39. Upchurch, G.R.; Ramdev, N.; Walsh, M.T.; Loscalzo, J. Prothrombotic consequences of the oxidation of fibrinogen and their inhibition by aspirin. J. Thromb. Thrombolysis 1998, 5, 9-14. [CrossRef]

40. De Cristofaro, R.; Landolfi, R. Oxidation of human alpha-thrombin by the myeloperoxidase- $\mathrm{H}_{2} \mathrm{O}_{2}$-chloride system: Structural and functional effects. Thromb. Haemost. 2000, 83, 253-261.

41. Van Patten, S.M.; Hanson, E.; Bernasconi, R.; Zhang, K.; Manavalan, P.; Cole, E.S.; McPherson, J.M.; Edmunds, T. Oxidation of methionine residues in antithrombin. Effects on biological activity and heparin binding. J. Biol. Chem. 1999, 274, 10268-10276. [CrossRef]

42. Gray, E.; Barrowcliffe, T.W. Inhibition of antithrombin III by lipid peroxides. Thromb. Res. 1985, 37, $241-250$. [CrossRef]

43. Huang, X.; Liu, B.; Wei, Y.; Beyea, R.; Yan, H.; Olson, S.T. Lipid oxidation inactivates the anticoagulant function of protein Z-dependent protease inhibitor (ZPI). J. Biol. Chem. 2017, 292, 14625-14635. [CrossRef] [PubMed]

44. Uderhardt, S.; Ackermann, J.A.; Fillep, T.; Hammond, V.J.; Willeit, J.; Santer, P.; Mayr, M.; Biburger, M.; Miller, M.; Zellner, K.R.; et al. Enzymatic lipid oxidation by eosinophils propagates coagulation, hemostasis, and thrombotic disease. J. Exp. Med. 2017, 214, 2121-2138. [CrossRef] [PubMed]

45. Von Brühl, M.-L.; Stark, K.; Steinhart, A.; Chandraratne, S.; Konrad, I.; Lorenz, M.; Khandoga, A.; Tirniceriu, A.; Coletti, R.; Köllnberger, M.; et al. Monocytes, neutrophils, and platelets cooperate to initiate and propagate venous thrombosis in mice in vivo. J. Exp. Med. 2012, 209, 819-835. [CrossRef]

46. Montoro-García, S.; Schindewolf, M.; Stanford, S.; Larsen, O.; Thiele, T. The role of platelets in venous thromboembolism. Semin. Thromb. Hemost. 2016, 42, 242-251. [CrossRef] 
47. Ay, C.; Jungbauer, L.V.; Sailer, T.; Tengler, T.; Koder, S.; Kaider, A.; Panzer, S.; Quehenberger, P.; Pabinger, I.; Mannhalter, C. High concentrations of soluble P-selectin are associated with risk of venous thromboembolism and the P-selectin Thr715 variant. Clin. Chem. 2007, 53, 1235-1243. [CrossRef]

48. Ay, C.; Dunkler, D.; Marosi, C.; Chiriac, A.-L.; Vormittag, R.; Simanek, R.; Quehenberger, P.; Zielinski, C.; Pabinger, I. Prediction of venous thromboembolism in cancer patients. Blood 2010, 116, 5377-5382. [CrossRef]

49. Etulain, J.; Martinod, K.; Wong, S.L.; Cifuni, S.M.; Schattner, M.; Wagner, D.D. P-selectin promotes neutrophil extracellular trap formation in mice. Blood 2015, 126, 242-246. [CrossRef]

50. Kim, K.; Li, J.; Tseng, A.; Andrews, R.K.; Cho, J. NOX2 is critical for heterotypic neutrophil-platelet interactions during vascular inflammation. Blood 2015, 126, 1952-1964. [CrossRef]

51. Pignatelli, P.; Sanguigni, V.; Lenti, L.; Ferro, D.; Finocchi, A.; Rossi, P.; Violi, F. gp91phox-dependent expression of platelet CD40 ligand. Circulation 2004, 110, 1326-1329. [CrossRef]

52. Colas, R.; Sassolas, A.; Guichardant, M.; Cugnet-Anceau, C.; Moret, M.; Moulin, P.; Lagarde, M.; Calzada, C. LDL from obese patients with the metabolic syndrome show increased lipid peroxidation and activate platelets. Diabetologia 2011, 54, 2931-2940. [CrossRef] [PubMed]

53. Carnevale, R.; Loffredo, L.; Sanguigni, V.; Plebani, A.; Rossi, P.; Pignata, C.; Martire, B.; Finocchi, A.; Pietrogrande, M.C.; Azzari, C.; et al. Different degrees of NADPH oxidase 2 regulation and in vivo platelet activation: Lesson from chronic granulomatous disease. J. Am. Heart Assoc. 2014, 3, e000920. [CrossRef] [PubMed]

54. Chakrabarti, S.; Varghese, S.; Vitseva, O.; Tanriverdi, K.; Freedman, J.E. CD40 ligand influences platelet release of reactive oxygen intermediates. Arterioscler. Thromb. Vasc. Biol. 2005, 25, 2428-2434. [CrossRef] [PubMed]

55. Pignatelli, P.; Carnevale, R.; Di Santo, S.; Bartimoccia, S.; Sanguigni, V.; Lenti, L.; Finocchi, A.; Mendolicchio, L.; Soresina, A.R.; Plebani, A.; et al. Inherited human gp91 ${ }^{\text {phox }}$ deficiency is associated with impaired isoprostane formation and platelet dysfunction. Arterioscler. Thromb. Vasc. Biol. 2011, 31, 423-434. [CrossRef]

56. Davi, G.; Alessandrini, P.; Mezzetti, A.; Minotti, G.; Bucciarelli, T.; Costantini, F.; Cipollone, F.; Bon, G.B.; Ciabattoni, G.; Patrono, C. In vivo formation of 8-epi-prostaglandin $\mathrm{F}_{2 \alpha}$ is increased in hypercholesterolemia. Arterioscler. Thromb. Vasc. Biol. 1997, 17, 3230-3235. [CrossRef]

57. Davì, G.; Ciabattoni, G.; Consoli, A.; Mezzetti, A.; Falco, A.; Santarone, S.; Pennese, E.; Vitacolonna, E.; Bucciarelli, T.; Costantini, F.; et al. In vivo formation of 8-iso-prostaglandin f2alpha and platelet activation in diabetes mellitus: Effects of improved metabolic control and vitamin E supplementation. Circulation 1999, 99, 224-229. [CrossRef]

58. Davì, G.; Di Minno, G.; Coppola, A.; Andria, G.; Cerbone, A.M.; Madonna, P.; Tufano, A.; Falco, A.; Marchesani, P.; Ciabattoni, G.; et al. Oxidative stress and platelet activation in homozygous homocystinuria. Circulation 2001, 104, 1124-1128. [CrossRef]

59. Davì, G.; Guagnano, M.T.; Ciabattoni, G.; Basili, S.; Falco, A.; Marinopiccoli, M.; Nutini, M.; Sensi, S.; Patrono, C. Platelet activation in obese women. JAMA 2002, 288, 2008. [CrossRef]

60. Ray, J.G. Meta-analysis of hyperhomocysteinemia as a risk factor for venous thromboembolic disease. Arch. Intern. Med. 1998, 158, 2101. [CrossRef]

61. Gregson, J.; Kaptoge, S.; Bolton, T.; Pennells, L.; Willeit, P.; Burgess, S.; Bell, S.; Sweeting, M.; Rimm, E.B.; Kabrhel, C.; et al. Cardiovascular risk factors associated with venous thromboembolism. JAMA Cardiol. 2019, 4, 163. [CrossRef]

62. Tajima, M.; Sakagami, H. Tetrahydrobiopterin impairs the action of endothelial nitric oxide via superoxide derived from platelets. Br. J. Pharm. 2000, 131, 958-964. [CrossRef] [PubMed]

63. Wang, B.; Yee Aw, T.; Stokes, K.Y. N-acetylcysteine attenuates systemic platelet activation and cerebral vessel thrombosis in diabetes. Redox Biol. 2018, 14, 218-228. [CrossRef] [PubMed]

64. Olas, B.; Wachowicz, B. Resveratrol and vitamin C as antioxidants in blood platelets. Thromb. Res. 2002, 106, 143-148. [CrossRef]

65. Pignatelli, P.; Pulcinelli, F.M.; Lenti, L.; Gazzaniga, P.P.; Violi, F. Vitamin E inhibits collagen-induced platelet activation by blunting hydrogen peroxide. Arterioscler. Thromb. Vasc. Biol. 1999, 19, 2542-2547. [CrossRef]

66. Jin, R.C.; Mahoney, C.E.; (Coleman) Anderson, L.; Ottaviano, F.; Croce, K.; Leopold, J.A.; Zhang, Y.-Y.; Tang, S.-S.; Handy, D.E.; Loscalzo, J. Glutathione peroxidase-3 deficiency promotes platelet-dependent thrombosis in vivo. Circulation 2011, 123, 1963-1973. [CrossRef] 
67. Dayal, S.; Wilson, K.M.; Motto, D.G.; Miller, F.J.; Chauhan, A.K.; Lentz, S.R. Hydrogen peroxide promotes aging-related platelet hyperactivation and thrombosis. Circulation 2013, 127, 1308-1316. [CrossRef]

68. Walsh, T.G.; Berndt, M.C.; Carrim, N.; Cowman, J.; Kenny, D.; Metharom, P. The role of Nox1 and Nox2 in GPVI-dependent platelet activation and thrombus formation. Redox Biol. 2014, 2, 178-186. [CrossRef]

69. Secor, D.; Li, F.; Ellis, C.G.; Sharpe, M.D.; Gross, P.L.; Wilson, J.X.; Tyml, K. Impaired microvascular perfusion in sepsis requires activated coagulation and P-selectin-mediated platelet adhesion in capillaries. Intensive Care Med. 2010, 36, 1928-1934. [CrossRef]

70. Delaney, M.K.; Kim, K.; Estevez, B.; Xu, Z.; Stojanovic-Terpo, A.; Shen, B.; Ushio-Fukai, M.; Cho, J.; Du, X. Differential roles of the NADPH-oxidase 1 and 2 in platelet activation and thrombosis. Arterioscler. Thromb. Vasc. Biol. 2016, 36, 846-854. [CrossRef]

71. Liu, Y.; Hu, M.; Luo, D.; Yue, M.; Wang, S.; Chen, X.; Zhou, Y.; Wang, Y.; Cai, Y.; Hu, X.; et al. Class III PI3K positively regulates platelet activation and thrombosis via PI(3)P-directed function of NADPH oxidase. Arterioscler. Thromb. Vasc. Biol. 2017, 37, 2075-2086. [CrossRef]

72. Brinkmann, V.; Reichard, U.; Goosmann, C.; Fauler, B.; Uhlemann, Y.; Weiss, D.S.; Weinrauch, Y.; Zychlinsky, A. Neutrophil extracellular traps kill bacteria. Science 2004, 303, 1532-1535. [CrossRef] [PubMed]

73. Kimball, A.S.; Obi, A.T.; Diaz, J.A.; Henke, P.K. The emerging role of NETs in venous thrombosis and immunothrombosis. Front. Immunol. 2016, 7, 236. [CrossRef] [PubMed]

74. Goldmann, O.; Medina, E. The expanding world of extracellular traps: Not only neutrophils but much more. Front. Immunol. 2013, 3, 420. [CrossRef] [PubMed]

75. Stoiber, W.; Obermayer, A.; Steinbacher, P.; Krautgartner, W.-D. The role of reactive oxygen species (ROS) in the formation of extracellular traps (ETs) in humans. Biomolecules 2015, 5, 702-723. [CrossRef] [PubMed]

76. Papayannopoulos, V.; Metzler, K.D.; Hakkim, A.; Zychlinsky, A. Neutrophil elastase and myeloperoxidase regulate the formation of neutrophil extracellular traps. J. Cell Biol. 2010, 191, 677-691. [CrossRef] [PubMed]

77. Li, P.; Li, M.; Lindberg, M.R.; Kennett, M.J.; Xiong, N.; Wang, Y. PAD4 is essential for antibacterial innate immunity mediated by neutrophil extracellular traps. J. Exp. Med. 2010, 207, 1853. [CrossRef]

78. Martinod, K.; Demers, M.; Fuchs, T.A.; Wong, S.L.; Brill, A.; Gallant, M.; Hu, J.; Wang, Y.; Wagner, D.D. Neutrophil histone modification by peptidylarginine deiminase 4 is critical for deep vein thrombosis in mice. Proc. Natl. Acad. Sci. USA 2013, 110, 8674-8679. [CrossRef]

79. Beckmann, L.; Dicke, C.; Spath, B.; Lehr, C.; Sievers, B.; Klinke, A.; Baldus, S.; Rudolph, V.; Langer, F. Myeloperoxidase is a negative regulator of phospholipid-dependent coagulation. Thromb. Haemost. 2017, 117, 2300-2311. [CrossRef]

80. d'Onofrio, G.; Mancini, R.; Vallone, R.; Alfano, G.; Candido, A.; Palla, M.; Mango, G. Acquired neutrophil myeloperoxidase deficiency: An indicator of subclinical activation of blood coagulation? Blood Cells 1983, 9 , 455-466.

81. Woollard, K.J.; Sturgeon, S.; Chin-Dusting, J.P.F.; Salem, H.H.; Jackson, S.P. Erythrocyte hemolysis and hemoglobin oxidation promote ferric chloride-induced vascular injury. J. Biol. Chem. 2009, 284, 13110-13118. [CrossRef]

82. Bahl, N.; Winarsih, I.; Tucker-Kellogg, L.; Ding, J.L. Extracellular haemoglobin upregulates and binds to tissue factor on macrophages: Implications for coagulation and oxidative stress. Thromb. Haemost. 2014, 111, 67-78. [CrossRef]

83. Tracz, M.J.; Juncos, J.P.; Grande, J.P.; Croatt, A.J.; Ackerman, A.W.; Katusic, Z.S.; Nath, K.A. Induction of heme oxygenase- 1 is a beneficial response in a murine model of venous thrombosis. Am. J. Pathol. 2008, 173, 1882-1890. [CrossRef] [PubMed]

84. Mustafa, S.; Weltermann, A.; Fritsche, R.; Marsik, C.; Wagner, O.; Kyrle, P.A.; Eichinger, S. Genetic variation in heme oxygenase 1 (HMOX1) and the risk of recurrent venous thromboembolism. J. Vasc. Surg. 2008, 47, 566-570. [CrossRef] [PubMed]

85. Chen, G.; Zhang, D.; Fuchs, T.A.; Manwani, D.; Wagner, D.D.; Frenette, P.S. Heme-induced neutrophil extracellular traps contribute to the pathogenesis of sickle cell disease. Blood 2014, 123, 3818-3827. [CrossRef] [PubMed]

86. Dutra, F.F.; Alves, L.S.; Rodrigues, D.; Fernandez, P.L.; De Oliveira, R.B.; Golenbock, D.T.; Zamboni, D.S.; Bozza, M.T. Hemolysis-induced lethality involves inflammasome activation by heme. Proc. Natl. Acad. Sci. USA 2014, 111, E4110-E4118. [CrossRef] 
87. Gupta, N.; Sahu, A.; Prabhakar, A.; Chatterjee, T.; Tyagi, T.; Kumari, B.; Khan, N.; Nair, V.; Bajaj, N.; Sharma, M.; et al. Activation of NLRP3 inflammasome complex potentiates venous thrombosis in response to hypoxia. Proc. Natl. Acad. Sci. USA 2017, 114, 4763-4768. [CrossRef]

88. Bankl, H.C.; Grobschmidt, K.; Pikula, B.; Bankl, H.; Lechner, K.; Valent, P. Mast cells are augmented in deep vein thrombosis and express a profibrinolytic phenotype. Hum. Pathol. 1999, 30, 188-194. [CrossRef]

89. Evans, C.E.; Humphries, J.; Mattock, K.; Waltham, M.; Wadoodi, A.; Saha, P.; Modarai, B.; Maxwell, P.H.; Maxwell, P.J.; Smith, A. Hypoxia and upregulation of hypoxia-inducible factor 1 \{alpha\} stimulate venous thrombus recanalization. Arterioscler. Thromb. Vasc. Biol. 2010, 30, 2443-2451. [CrossRef]

90. Brooks, A.C.; Whelan, C.J.; Purcell, W.M. Reactive oxygen species generation and histamine release by activated mast cells: Modulation by nitric oxide synthase inhibition. Br. J. Pharm. 1999, 128, 585-590. [CrossRef]

91. Krystel-Whittemore, M.; Dileepan, K.N.; Wood, J.G. Mast cell: A multi-functional master cell. Front. Immunol. 2015, 6, 620. [CrossRef]

92. Li, Z.Y.; Jiang, W.Y.; Cui, Z.J. An essential role of NAD(P)H oxidase 2 in UVA-induced calcium oscillations in mast cells. Photochem. Photobiol. Sci. 2015, 14, 414-428. [CrossRef] [PubMed]

93. Chelombitko, M.A.; Fedorov, A.V.; Ilyinskaya, O.P.; Zinovkin, R.A.; Chernyak, B.V. Role of reactive oxygen species in mast cell degranulation. Biochemistry 2016, 81, 1564-1577. [CrossRef] [PubMed]

94. Norgaard, I.; Nielsen, S.F.; Nordestgaard, B.G. Complement C3 and high risk of venous thromboembolism: 80517 individuals from the copenhagen general population study. Clin. Chem. 2016, 62, 525-534. [CrossRef] [PubMed]

95. Foley, J.H.; Walton, B.L.; Aleman, M.M.; O’Byrne, A.M.; Lei, V.; Harrasser, M.; Foley, K.A.; Wolberg, A.S.; Conway, E.M. Complement in activation arteriosclerial and venous thrombosis is mediated by plasmin. EBioMedicine 2016, 5, 175-182. [CrossRef] [PubMed]

96. Barrett, C.D.; Hsu, A.T.; Ellson, C.D.; Y.Miyazawa, B.; Kong, Y.-W.; Greenwood, J.D.; Dhara, S.; Neal, M.D.; Sperry, J.L.; Park, M.S.; et al. Blood clotting and traumatic injury with shock mediates complement-dependent neutrophil priming for extracellular ROS, ROS-dependent organ injury and coagulopathy. Clin. Exp. Immunol. 2018, 194, 103-117. [CrossRef]

97. Prins, D.; Groenendyk, J.; Touret, N.; Michalak, M. Modulation of STIM1 and capacitative Ca ${ }^{2+}$ entry by the endoplasmic reticulum luminal oxidoreductase ERp57. EMBO Rep. 2011, 12, 1182-1188. [CrossRef]

98. Hawkins, B.J.; Irrinki, K.M.; Mallilankaraman, K.; Lien, Y.C.; Wang, Y.; Bhanumathy, C.D.; Subbiah, R.; Ritchie, M.F.; Soboloff, J.; Baba, Y.; et al. S-glutathionylation activates STIM1 and alters mitochondrial homeostasis. J. Cell Biol. 2010, 190, 391-405. [CrossRef]

99. Kim, E.Y.; Anderson, M.; Wilson, C.; Hagmann, H.; Benzing, T.; Dryer, S.E. NOX2 interacts with podocyte TRPC6 channels and contributes to their activation by diacylglycerol: Essential role of podocin in formation of this complex. Am. J. Physiol. Cell Physiol. 2013, 305, C960-C971. [CrossRef]

100. Song, X.; Liu, B.C.; Lu, X.Y.; Yang, L.L.; Zhai, Y.J.; Eaton, A.F.; Thai, T.L.; Eaton, D.C.; Ma, H.P.; Shen, B.Z. Lovastatin inhibits human B lymphoma cell proliferation by reducing intracellular ROS and TRPC6 expression. Biochim. Biophys. Acta Mol. Cell Res. 2014, 1843, 894-901. [CrossRef]

101. Rigutto, S.; Hoste, C.; Grasberger, H.; Milenkovic, M.; Communi, D.; Dumont, J.E.; Corvilain, B.; Miot, F.; De Deken, X. Activation of dual oxidases Duox1 and Duox2: Differential regulation mediated by cAMP-dependent protein kinase and protein kinase C-dependent phosphorylation. J. Biol. Chem. 2009, 284, 6725-6734. [CrossRef]

102. Jagnandan, D.; Church, J.E.; Banfi, B.; Stuehr, D.J.; Marrero, M.B.; Fulton, D.J.R. Novel mechanism of activation of NADPH oxidase 5: Calcium sensitization via phosphorylation. J. Biol. Chem. 2007, 282, 6494-6507. [CrossRef] [PubMed]

103. El Jamali, A.; Valente, A.J.; Clark, R.A. Regulation of phagocyte NADPH oxidase by hydrogen peroxide through a $\mathrm{Ca}^{2+} / \mathrm{c}-\mathrm{Abl}$ signaling pathway. Free Radic. Biol. Med. 2010, 48, 798-810. [CrossRef] [PubMed]

104. Varga-Szabo, D.; Braun, A.; Nieswandt, B. Calcium signaling in platelets. J. Thromb. Haemost. 2009, 7, 1057-1066. [CrossRef] [PubMed]

105. Li, J.; Cubbon, R.M.; Wilson, L.A.; Amer, M.S.; McKeown, L.; Hou, B.; Majeed, Y.; Tumova, S.; Seymour, V.A.L.; Taylor, H.; et al. Orai1 and CRAC channel dependence of VEGF-activated $\mathrm{Ca}^{2+}$ entry and endothelial tube formation. Circ. Res. 2011, 108, 1190-1198. [CrossRef] 
106. Northeast, A.D.; Soo, K.S.; Bobrow, L.G.; Gaffney, P.J.; Burnand, K.G. The tissue plasminogen activator and urokinase response in vivo during natural resolution of venous thrombus. J. Vasc. Surg. 1995, 22, 573-579. [CrossRef]

107. Soo, K.S.; Northeast, A.D.R.; Happerfield, L.C.; Burnand, K.G.; Bobrow, L.G. Tissue plasminogen activator production by monocytes in venous thrombolysis. J. Pathol. 1996, 178, 190-194. [CrossRef]

108. Singh, I.; Burnand, K.G.; Collins, M.; Luttun, A.; Collen, D.; Boelhouwer, B.; Smith, A. Failure of thrombus to resolve in urokinase-type plasminogen activator gene-knockout mice. Circulation 2003, 107, 869-875. [CrossRef]

109. Gossage, J.A.; Humphries, J.; Modarai, B.; Burnand, K.G.; Smith, A. Adenoviral urokinase-type plasminogen activator (uPA) gene transfer enhances venous thrombus resolution. J. Vasc. Surg. 2006, 44, 1085-1090. [CrossRef]

110. Siefert, S.A.; Chabasse, C.; Mukhopadhyay, S.; Hoofnagle, M.H.; Strickland, D.K.; Sarkar, R.; Antalis, T.M. Enhanced venous thrombus resolution in plasminogen activator inhibitor type-2 deficient mice. J. Thromb. Haemost. 2014, 12, 1706-1716. [CrossRef]

111. Okada, H.; Woodcock-Mitchell, J.; Mitchell, J.; Sakamoto, T.; Marutsuka, K.; Sobel, B.E.; Fujii, S. Induction of plasminogen activator inhibitor type 1 and type 1 collagen expression in rat cardiac microvascular endothelial cells by interleukin-1 and its dependence on oxygen-centered free radicals. Circulation 1998, 97, 2175-2182. [CrossRef]

112. Görlach, A.; Diebold, I.; Schini-Kerth, V.B.; Berchner-Pfannschmidt, U.; Roth, U.; Brandes, R.P.; Kietzmann, T.; Busse, R. Thrombin activates the hypoxia-inducible factor- 1 signaling pathway in vascular smooth muscle cells: Role of the p22(phox)-containing NADPH oxidase. Circ. Res. 2001, 89, 47-54. [CrossRef] [PubMed]

113. Dimova, E.Y.; Samoylenko, A.; Kietzmann, T. Oxidative Stress and Hypoxia: Implications for Plasminogen Activator Inhibitor-1 Expression. Antioxid. Redox Signal. 2004, 6, 777-791. [CrossRef]

114. Jaulmes, A.; Sansilvestri-Morel, P.; Rolland-Valognes, G.; Bernhardt, F.; Gaertner, R.; Lockhart, B.P.; Cordi, A.; Wierzbicki, M.; Rupin, A.; Verbeuren, T.J. Nox4 mediates the expression of plasminogen activator inhibitor-1 via p38 MAPK pathway in cultured human endothelial cells. Thromb. Res. 2009, 124, 439-446. [CrossRef] [PubMed]

115. Vulin, A.I.; Stanley, F.M. Oxidative stress activates the plasminogen activator inhibitor type 1 (PAI-1) promoter through an AP-1 response element and cooperates with insulin for additive effects on PAI-1 transcription. J. Biol. Chem. 2004, 279, 25172-25178. [CrossRef]

116. Miyamoto, S.; Kawano, H.; Takazoe, K.; Soejima, H.; Sakamoto, T.; Hokamaki, J.; Yoshimura, M.; Nakamura, H.; Yodoi, J.; Ogawa, H. Vitamin E improves fibrinolytic activity in patients with coronary spastic angina. Thromb. Res. 2004, 113, 345-351. [CrossRef] [PubMed]

117. Lawrence, D.A.; Loskutoff, D.J. Inactivation of plasminogen activator inhibitor by oxidants. Biochemistry 1986, 25, 6351-6355. [CrossRef] [PubMed]

118. Görlach, A.; Berchner-Pfannschmidt, U.; Wotzlaw, C.; Cool, R.H.; Fandrey, J.; Acker, H.; Jungermann, K.; Kietzmann, T. Reactive oxygen species modulate HIF-1 mediated PAI-1 expression: Involvement of the GTPase Rac1. Thromb. Haemost. 2003, 89, 926-935.

119. Uchida, Y.; Ohba, K.; Yoshioka, T.; Irie, K.; Muraki, T.; Maru, Y. Cellular carbonyl stress enhances the expression of plasminogen activator inhibitor-1 in rat white adipocytes via reactive oxygen species-dependent pathway. J. Biol. Chem. 2004, 279, 4075-4083. [CrossRef]

120. Wagenaar, G.T.; Ter Horst, S.A.; Van Gastelen, M.A.; Leijser, L.M.; Mauad, T.; Van Der Velden, P.A.; De Heer, E.; Hiemstra, P.S.; Poorthuis, B.J.H.; Walther, F.J. Gene expression profile and histopathology of experimental bronchopulmonary dysplasia induced by prolonged oxidative stress. Free Radic. Biol. Med. 2004, 36, 782-801. [CrossRef]

121. Franke, K.; Curth, K.; Lenart, J.; Knochenhauer, D.; Kietzmann, T. Enhanced plasminogen activator inhibitor-1 expression in transgenic mice with hepatocyte-specific overexpression of superoxide dismutase or glutathione peroxidase. Antioxid. Redox Signal. 2004, 6, 721-728. [CrossRef]

122. Varma, M.R.; Varga, A.J.; Knipp, B.S.; Sukheepod, P.; Upchurch, G.R.; Kunkel, S.L.; Wakefield, T.W.; Henke, P.K. Neutropenia impairs venous thrombosis resolution in the rat. J. Vasc. Surg. 2003, 38, 1090-1098. [CrossRef] 
123. Ali, T.; Humphries, J.; Burnand, K.; Sawyer, B.; Bursill, C.; Channon, K.; Greaves, D.; Rollins, B.; Charo, I.F.; Smith, A. Monocyte recruitment in venous thrombus resolution. J. Vasc. Surg. 2006, 43, 601-608. [CrossRef] [PubMed]

124. Klyubin, I.V.; Kirpichnikova, K.M.; Gamaley, I.A. Hydrogen peroxide-induced chemotaxis of mouse peritoneal neutrophils. Eur. J. Cell Biol. 1996, 70, 347-351. [PubMed]

125. Tur, E.; Bolton, L.; Constantine, B.E. Topical hydrogen peroxide treatment of ischemic ulcers in the guinea pig: Blood recruitment in multiple skin sites. J. Am. Acad. Dermatol. 1995, 33, 217-221. [CrossRef]

126. Nakamura, H.; Herzenberg, L.A.; Bai, J.; Araya, S.; Kondo, N.; Nishinaka, Y.; Herzenberg, L.A.; Yodoi, J. Circulating thioredoxin suppresses lipopolysaccharide-induced neutrophil chemotaxis. Proc. Natl. Acad. Sci. USA 2001, 98, 15143-15148. [CrossRef]

127. Fraticelli, A.; Serrano, C.V.; Bochner, B.S.; Capogrossi, M.C.; Zweier, J.L. Hydrogen peroxide and superoxide modulate leukocyte adhesion molecule expression and leukocyte endothelial adhesion. Biochim. Biophys. Acta Mol. Cell Res. 1996, 1310, 251-259. [CrossRef]

128. Kellermair, J.; Redwan, B.; Alias, S.; Jabkowski, J.; Panzenboeck, A.; Kellermair, L.; Winter, M.P.; Weltermann, A.; Lang, I.M. Platelet endothelial cell adhesion molecule 1 deficiency misguides venous thrombus resolution. Blood 2013, 122, 3376-3384. [CrossRef]

129. Rattan, V.; Sultana, C.; Shen, Y.; Kalra, V.K. Oxidant stress-induced transendothelial migration of monocytes is linked to phosphorylation of PECAM-1. Am. J. Physiol. Metab. 1997, 273, E453. [CrossRef]

130. Saragih, H.; Zilian, E.; Jaimes, Y.; Paine, A.; Figueiredo, C.; Eiz-Vesper, B.; Blasczyk, R.; Larmann, J.; Theilmeier, G.; Burg-Roderfeld, M.; et al. PECAM-1-dependent heme oxygenase-1 regulation via an Nrf2-mediated pathway in endothelial cells. Thromb. Haemost. 2014, 111, 1077-1088.

131. Van Aken, B.E.; Reitsma, P.H.; Rosendaal, F.R. Interleukin 8 and venous thrombosis: Evidence for a role of inflammation in thrombosis. Br. J. Haematol. 2002, 116, 173-177. [CrossRef]

132. Henke, P.K.; Wakefield, T.W.; Kadell, A.M.; Linn, M.J.; Varma, M.R.; Sarkar, M.; Hawley, A.; Fowlkes, J.B.; Strieter, R.M. Interleukin-8 administration enhances venous thrombosis resolution in a rat model. J. Surg. Res. 2001, 99, 84-91. [CrossRef] [PubMed]

133. Lekstrom-Himes, J.A.; Kuhns, D.B.; Alvord, W.G.; Gallin, J.I. Inhibition of human neutrophil IL-8 production by hydrogen peroxide and dysregulation in chronic granulomatous disease. J. Immunol. 2005, 174, 411-417. [CrossRef] [PubMed]

134. Zmijewski, J.W.; Zhao, X.; Xu, Z.; Abraham, E. Exposure to hydrogen peroxide diminishes NF-kB activation, IкB- $\alpha$ degradation, and proteasome activity in neutrophils. Am. J. Physiol. Physiol. 2007, 293, C255-C266. [CrossRef] [PubMed]

135. DeForge, L.E.; Preston, A.M.; Takeuchi, E.; Kenney, J.; Boxer, L.A.; Remick, D.G. Regulation of interleukin 8 gene expression by oxidant stress. J. Biol. Chem. 1993, 268, 25568-25576.

136. Monteseirín, J.; Chacón, P.; Vega, A.; El Bekay, R.; Alvarez, M.; Alba, G.; Conde, M.; Jiménez, J.; Asturias, J.A.; Martínez, A.; et al. Human neutrophils synthesize IL-8 in an IgE-mediated activation. J. Leukoc. Biol. 2004, 76, 692-700. [CrossRef]

137. Hidalgo, M.A.; Carretta, M.D.; Teuber, S.E.; Zárate, C.; Cárcamo, L.; Concha, I.I.; Burgos, R.A. fMLP-induced IL-8 release is dependent on NADPH oxidase in human neutrophils. J. Immunol. Res. 2015, 2015, 120348. [CrossRef]

138. Miyoshi, T.; Yamashita, K.; Arai, T.; Yamamoto, K.; Mizugishi, K.; Uchiyama, T. The role of endothelial interleukin-8/NADPH oxidase 1 axis in sepsis. Immunology 2010, 131, 331-339. [CrossRef]

139. Yadav, A.; Saini, V.; Arora, S. MCP-1: Chemoattractant with a role beyond immunity: A review. Clin. Chim. Acta 2010, 411, 1570-1579. [CrossRef]

140. Humphries, J.; McGuinness, C.L.; Smith, A.; Waltham, M.; Poston, R.; Burnand, K.G. Monocyte chemotactic protein-1 (MCP-1) accelerates the organization and resolution of venous thrombi. J. Vasc. Surg. 1999, 30, 894-899. [CrossRef]

141. Lee, Y.W.; Lee, W.H.; Kim, P.H. Role of NADPH oxidase in interleukin-4-induced monocyte chemoattractant protein-1 expression in vascular endothelium. Inflamm. Res. 2010, 59, 755-765. [CrossRef]

142. Zhang, W.; Rojas, M.; Lilly, B.; Tsai, N.-T.; Lemtalsi, T.; Liou, G.I.; Caldwell, R.W.; Caldwell, R.B. NAD(P)H oxidase-dependent regulation of CCL2 production during retinal inflammation. Investig. Ophthalmol. Vis. Sci. 2009, 50, 3033-3040. [CrossRef] [PubMed] 
143. Sasaki, Y.; Dehnad, A.; Fish, S.; Sato, A.; Jiang, J.; Tian, J.; Schröder, K.; Brandes, R.; Török, N.J. NOX4 regulates CCR2 and CCL2 mRNA stability in alcoholic liver disease. Sci. Rep. 2017, 7, 46144. [CrossRef] [PubMed]

144. Cushing, S.D.; Berliner, J.A.; Valente, A.J.; Territo, M.C.; Navab, M.; Parhami, F.; Gerrity, R.; Schwartz, C.J.; Fogelman, A.M. Minimally modified low density lipoprotein induces monocyte chemotactic protein 1 in human endothelial cells and smooth muscle cells. Proc. Natl. Acad. Sci. USA 1990, 87, 5134-5138. [CrossRef] [PubMed]

145. Modarai, B.; Humphries, J.; Gossage, J.A.; Waltham, M.; Burnand, K.G.; Kanaganayagam, G.S.; Afuwape, A.; Paleolog, E.; Smith, A.; Wadoodi, A. Adenovirus-mediated VEGF gene therapy enhances venous thrombus recanalization and resolution. Arterioscler. Thromb. Vasc. Biol. 2008, 28, 1753-1759. [CrossRef]

146. Evans, C.E.; Grover, S.P.; Humphries, J.; Saha, P.; Patel, A.P.; Patel, A.S.; Lyons, O.T.; Waltham, M.; Modarai, B.; Smith, A. Antiangiogenic therapy inhibits venous thrombus resolution. Arterioscler. Thromb. Vasc. Biol. 2014, 34, 565-570. [CrossRef]

147. Altmann, J.; Sharma, S.; Lang, I.M. Advances in our understanding of mechanisms of venous thrombus resolution. Expert Rev. Hematol. 2016, 9, 69-78. [CrossRef]

148. Salcedo, R.; Ponce, M.L.; Young, H.A.; Wasserman, K.; Ward, J.M.; Kleinman, H.K.; Oppenheim, J.J.; Murphy, W.J. Human endothelial cells express CCR2 and respond to MCP-1: Direct role of MCP-1 in angiogenesis and tumor progression. Blood 2000, 96, 34-40. [CrossRef]

149. Kim, Y.-W.; Byzova, T. V Oxidative stress in angiogenesis and vascular disease. Blood 2014, 123, 625-631. [CrossRef]

150. West, X.Z.; Malinin, N.L.; Merkulova, A.A.; Tischenko, M.; Kerr, B.A.; Borden, E.C.; Podrez, E.A.; Salomon, R.G.; Byzova, T.V. Oxidative stress induces angiogenesis by activating TLR2 with novel endogenous ligands. Nature 2010, 467, 972-976. [CrossRef]

151. Gengrinovitch, S.; Berman, B.; David, G.; Witte, L.; Neufeld, G.; Ron, D. Glypican-1 is a VEGF 165 binding proteoglycan that acts as an extracellular chaperone for $\mathrm{VEGF}_{165}$. J. Biol. Chem. 1999, 274, 10816-10822. [CrossRef]

152. BelAiba, R.S.; Djordjevic, T.; Petry, A.; Diemer, K.; Bonello, S.; Banfi, B.; Hess, J.; Pogrebniak, A.; Bickel, C.; Görlach, A. NOX5 variants are functionally active in endothelial cells. Free Radic. Biol. Med. 2007, 42, 446-459. [CrossRef]

153. Al-Shabrawey, M.; Bartoli, M.; El-Remessy, A.B.; Platt, D.H.; Matragoon, S.; Behzadian, M.A.; Caldwell, R.W.; Caldwell, R.B. Inhibition of $\mathrm{NAD}(\mathrm{P}) \mathrm{H}$ oxidase activity blocks vascular endothelial growth factor overexpression and neovascularization during ischemic retinopathy. Am. J. Pathol. 2005, 167, 599-607. [CrossRef]

154. Cai, T.; Fassina, G.; Morini, M.; Aluigi, M.G.; Masiello, L.; Fontanini, G.; D'Agostini, F.; De Flora, S.; Noonan, D.M.; Albini, A. N-acetylcysteine inhibits endothelial cell invasion and angiogenesis. Lab. Investig. 1999, 79, 1151-1159.

155. Wheeler, M.D.; Smutney, O.M.; Samulski, R.J. Secretion of extracellular superoxide dismutase from muscle transduced with recombinant adenovirus inhibits the growth of B16 melanomas in mice. Mol. Cancer Res. 2003, 1, 871-881.

156. Hecker, L.; Vittal, R.; Jones, T.; Jagirdar, R.; Luckhardt, T.R.; Horowitz, J.C.; Pennathur, S.; Martinez, F.J.; Thannickal, V.J. NADPH oxidase-4 mediates myofibroblast activation and fibrogenic responses to lung injury. Nat. Med. 2009, 15, 1077-1081. [CrossRef]

157. Carnesecchi, S.; Deffert, C.; Donati, Y.; Basset, O.; Hinz, B.; Preynat-Seauve, O.; Guichard, C.; Arbiser, J.L.; Banfi, B.; Pache, J.-C.; et al. A key role for NOX4 in epithelial cell death during development of lung fibrosis. Antioxid. Redox Signal. 2011, 15, 607-619. [CrossRef]

158. Sturrock, A.; Cahill, B.; Norman, K.; Huecksteadt, T.P.; Hill, K.; Sanders, K.; Karwande, S.V.; Stringham, J.C.; Bull, D.A.; Gleich, M.; et al. Transforming growth factor- $\beta 1$ induces Nox4 NAD(P)H oxidase and reactive oxygen species-dependent proliferation in human pulmonary Arteriosclery smooth muscle cells. Am. J. Physiol. Cell. Mol. Physiol. 2006, 290, L661-L673. [CrossRef]

159. Cucoranu, I.; Clempus, R.; Dikalova, A.; Phelan, P.J.; Ariyan, S.; Dikalov, S.; Sorescu, D. NAD(P)H oxidase 4 mediates transforming growth factor- $\beta 1$-induced differentiation of cardiac fibroblasts into myofibroblasts. Circ. Res. 2005, 97, 900-907. [CrossRef] 
160. Zhang, G.-Y.; Wu, L.-C.; Dai, T.; Chen, S.-Y.; Wang, A.-Y.; Lin, K.; Lin, D.-M.; Yang, J.-Q.; Cheng, B.; Zhang, L.; et al. NADPH oxidase-2 is a key regulator of human dermal fibroblasts: A potential therapeutic strategy for the treatment of skin fibrosis. Exp. Dermatol. 2014, 23, 639-644. [CrossRef]

161. Lévigne, D.; Modarressi, A.; Krause, K.-H.; Pittet-Cuénod, B. NADPH oxidase 4 deficiency leads to impaired wound repair and reduced dityrosine-crosslinking, but does not affect myofibroblast formation. Free Radic. Biol. Med. 2016, 96, 374-384. [CrossRef]

162. Brandt, M.; Giokoglu, E.; Garlapati, V.; Bochenek, M.L.; Molitor, M.; Hobohm, L.; Schönfelder, T.; Münzel, T.; Kossmann, S.; Karbach, S.H.; et al. Pulmonary arteriosclerial hypertension and endothelial dysfunction is linked to NADPH oxidase-derived superoxide formation in venous thrombosis and pulmonary embolism in mice. Oxid. Med. Cell. Longev. 2018, 2018, 1-10. [CrossRef]

163. Jobi, K.; Rauch, B.H.; Dangwal, S.; Freidel, K.; Doller, A.; Eberhardt, W.; Fischer, J.W.; Schrör, K.; Rosenkranz, A.C. Redox regulation of human protease-activated receptor-2 by activated factor X. Free Radic. Biol. Med. 2011, 51, 1758-1764. [CrossRef]

164. Henke, P.; Varma, M.; Deatrick, K.; Dewyer, N.; Lynch, E.; Moore, A.; Dubay, D.; Sukheepod, P.; Pearce, C.; Upchurch, G.; et al. Neutrophils modulate post-thrombotic vein wall remodeling but not thrombus neovascularization. Thromb. Haemost. 2006, 95, 272-281.

165. Henke, P.K.; Varma, M.R.; Moaveni, D.K.; Dewyer, N.A.; Moore, A.J.; Lynch, E.M.; Longo, C.; Deatrick, C.B.; Kunkel, S.L.; Upchurch, G.R.; et al. Fibrotic injury after experimental deep vein thrombosis is determined by the mechanism of thrombogenesis. Thromb. Haemost. 2007, 98, 1045-1055.

166. Levi, E.; Fridman, R.; Miao, H.Q.; Ma, Y.S.; Yayon, A.; Vlodavsky, I. Matrix metalloproteinase 2 releases active soluble ectodomain of fibroblast growth factor receptor 1. Proc. Natl. Acad. Sci. USA 1996, 93, 7069-7074. [CrossRef]

167. Ugwu, F.; Van Hoef, B.; Bini, A.; Collen, D.; Lijnen, H.R. Proteolytic cleavage of urokinase-type plasminogen activator by stromelysin-1 (MMP-3). Biochemistry 1998, 37, 7231-7236. [CrossRef]

168. Collen, A.; Hanemaaijer, R.; Lupu, F.; Quax, P.H.A.; Van Lent, N.; Grimbergen, J.; Peters, E.; Koolwijk, P.; Van Hinsbergh, V.W.M. Membrane-type matrix metalloproteinase-mediated angiogenesis in a fibrin-collagen matrix. Blood 2003, 101, 1810-1817. [CrossRef]

169. Li, W.-D.; Li, X.-Q. Endothelial progenitor cells accelerate the resolution of deep vein thrombosis. Vasc. Pharm. 2016, 83, 10-16. [CrossRef] [PubMed]

170. Deatrick, K.B.; Eliason, J.L.; Lynch, E.M.; Moore, A.J.; Dewyer, N.A.; Varma, M.R.; Pearce, C.G.; Upchurch, G.R.; Wakefield, T.W.; Henke, P.K. Vein wall remodeling after deep vein thrombosis involves matrix metalloproteinases and late fibrosis in a mouse model. J. Vasc. Surg. 2005, 42, 140-148. [CrossRef]

171. Deatrick, K.B.; Obi, A.; Luke, C.E.; Elfline, M.A.; Sood, V.; Upchurch, G.R.; Jaffer, F.; Wakefield, T.W.; Henke, P.K. Matrix metalloproteinase-9 deletion is associated with decreased mid-term vein wall fibrosis in experimental stasis DVT. Thromb. Res. 2013, 132, 360-366. [CrossRef]

172. Henke, P.K.; Pearce, C.G.; Moaveni, D.M.; Moore, A.J.; Lynch, E.M.; Longo, C.; Varma, M.; Dewyer, N.A.; Deatrick, K.B.; Upchurch, G.R.; et al. Targeted deletion of CCR2 impairs deep vein thombosis resolution in a mouse model. J. Immunol. 2006, 177, 3388-3397. [CrossRef]

173. Nelson, K.K.; Melendez, J.A. Mitochondrial redox control of matrix metalloproteinases. Free Radic. Biol. Med. 2004, 37, 768-784. [CrossRef] [PubMed]

174. Belkhiri, A.; Richards, C.; Whaley, M.; McQueen, S.A.; Orr, F.W. Increased expression of activated matrix metalloproteinase-2 by human endothelial cells after sublethal $\mathrm{H}_{2} \mathrm{O}_{2}$ exposure. Lab. Investig. 1997, 77, 533-539. [PubMed]

175. Rajagopalan, S.; Meng, X.P.; Ramasamy, S.; Harrison, D.G.; Galis, Z.S. Reactive oxygen species produced by macrophage-derived foam cells regulate the activity of vascular matrix metalloproteinases in vitro. Implications for atherosclerotic plaque stability. J. Clin. Investig. 1996, 98, 2572-2579. [CrossRef] [PubMed]

176. Yoon, S.-O.; Park, S.-J.; Yoon, S.Y.; Yun, C.-H.; Chung, A.-S. Sustained production of $\mathrm{H}_{2} \mathrm{O}_{2}$ activates pro-matrix metalloproteinase-2 through receptor tyrosine kinases/phosphatidylinositol 3-kinase/NF- $\mathrm{kB}$ pathway. J. Biol. Chem. 2002, 277, 30271-30282. [CrossRef]

177. Shin, M.H.; Moon, Y.J.; Seo, J.-E.; Lee, Y.; Kim, K.H.; Chung, J.H. Reactive oxygen species produced by NADPH oxidase, xanthine oxidase, and mitochondrial electron transport system mediate heat shock-induced MMP-1 and MMP-9 expression. Free Radic. Biol. Med. 2008, 44, 635-645. [CrossRef] 
178. Poitevin, S.; Garnotel, R.; Antonicelli, F.; Gillery, P.; Nguyen, P. Type I collagen induces tissue factor expression and matrix metalloproteinase 9 production in human primary monocytes through a redox-sensitive pathway. J. Thromb. Haemost. 2008, 6, 1586-1594. [CrossRef]

179. Galis, Z.S.; Asanuma, K.; Godin, D.; Meng, X. N-acetyl-cysteine decreases the matrix-degrading capacity of macrophage-derived foam cells: New target for antioxidant therapy? Circulation 1998, 97, 2445-2453. [CrossRef]

180. Zhang, H.J.; Zhao, W.; Venkataraman, S.; Robbins, M.E.C.; Buettner, G.R.; Kregel, K.C.; Oberley, L.W. Activation of matrix metalloproteinase- 2 by overexpression of manganese superoxide dismutase in human breast cancer MCF-7 cells involves reactive oxygen species. J. Biol. Chem. 2002, 277, 20919-20926. [CrossRef]

181. Svineng, G.; Ravuri, C.; Rikardsen, O.; Huseby, N.-E.; Winberg, J.-O. The role of reactive oxygen species in integrin and matrix metalloproteinase expression and function. Connect. Tissue Res. 2008, 49, 197-202. [CrossRef]

182. Lackner, K.J.; Manukyan, D.; Müller-Calleja, N. Endosomal redox signaling in the antiphospholipid syndrome. Curr. Rheumatol. Rep. 2017, 19, 20. [CrossRef] [PubMed]

183. Manukyan, D.; Müller-Calleja, N.; Jäckel, S.; Luchmann, K.; Mönnikes, R.; Kiouptsi, K.; Reinhardt, C.; Jurk, K.; Walter, U.; Lackner, K.J. Cofactor-independent human antiphospholipid antibodies induce venous thrombosis in mice. J. Thromb. Haemost. 2016, 14, 1011-1020. [CrossRef] [PubMed]

184. Giannakopoulos, B.; Gao, L.; Qi, M.; Wong, J.W.; Yu, D.M.; Vlachoyiannopoulos, P.G.; Moutsopoulos, H.M.; Atsumi, T.; Koike, T.; Hogg, P.; et al. Factor XI is a substrate for oxidoreductases: Enhanced activation of reduced FXI and its role in antiphospholipid syndrome thrombosis. J. Autoimmun. 2012, 39, 121-129. [CrossRef]

185. Müller-Calleja, N.; Manukyan, D.; Canisius, A.; Strand, D.; Lackner, K.J. Hydroxychloroquine inhibits proinflammatory signalling pathways by targeting endosomal NADPH oxidase. Ann. Rheum. Dis. 2017, 76, 891-897. [CrossRef] [PubMed]

186. Becatti, M.; Emmi, G.; Silvestri, E.; Bruschi, G.; Ciucciarelli, L.; Squatrito, D.; Vaglio, A.; Taddei, N.; Abbate, R.; Emmi, L.; et al. Neutrophil activation promotes fibrinogen oxidation and thrombus formation in Behçet disease. Circulation 2016, 133, 302-311. [CrossRef] [PubMed]

187. Baccarelli, A.; Martinelli, I.; Zanobetti, A.; Grillo, P.; Hou, L.-F.; Bertazzi, P.A.; Mannucci, P.M.; Schwartz, J. Exposure to particulate air pollution and risk of deep vein thrombosis. Arch. Intern. Med. 2008, 168, 920-927. [CrossRef]

188. Snow, S.J.; Cheng, W.; Wolberg, A.S.; Carraway, M.S. Air pollution upregulates endothelial cell procoagulant activity via ultrafine particle-induced oxidant signaling and tissue factor expression. Toxicol. Sci. 2014, 140, 83-93. [CrossRef]

189. Ageno, W.; Prandoni, P.; Romualdi, E.; Ghirarduzzi, A.; Dentali, F.; Pesavento, R.; Crowther, M.; Venco, A. The metabolic syndrome and the risk of venous thrombosis: A case-control study. J. Thromb. Haemost. 2006, 4, 1914-1918. [CrossRef]

190. Magwenzi, S.; Woodward, C.; Wraith, K.S.; Aburima, A.; Raslan, Z.; Jones, H.; McNeil, C.; Wheatcroft, S.; Yuldasheva, N.; Febbriao, M.; et al. Oxidized LDL activates blood platelets through CD36/NOX2-mediated inhibition of the cGMP/protein kinase G signaling cascade. Blood 2015, 125, 2693-2703. [CrossRef]

191. Miller, M.W.; Sadeh, N. Traumatic stress, oxidative stress and post-traumatic stress disorder: Neurodegeneration and the accelerated-aging hypothesis. Mol. Psychiatry 2014, 19, 1156-1162. [CrossRef]

192. Dong, T.; Cheng, Y.-W.; Yang, F.; Sun, P.-W.; Zhu, C.-J.; Zhu, L.; Zhang, G.-X. Chronic stress facilitates the development of deep venous thrombosis. Oxid. Med. Cell. Longev. 2015, 2015, 384535. [CrossRef] [PubMed]

193. Yisireyili, M.; Takeshita, K.; Hayashi, M.; Wu, H.; Uchida, Y.; Yamamoto, K.; Kikuchi, R.; Hao, C.-N.; Nakayama, T.; Cheng, X.W.; et al. Dipeptidyl peptidase-IV inhibitor alogliptin improves stress-induced insulin resistance and prothrombotic state in a murine model. Psychoneuroendocrinology 2016, 73, 186-195. [CrossRef] [PubMed]

194. Yang, J.; Zhou, X.; Fan, X.; Xiao, M.; Yang, D.; Liang, B.; Dai, M.; Shan, L.; Lu, J.; Lin, Z.; et al. mTORC1 promotes aging-related venous thrombosis in mice via elevation of platelet volume and activation. Blood 2016, 128, 615-624. [CrossRef] [PubMed] 
195. Milman, U.; Blum, S.; Shapira, C.; Aronson, D.; Miller-Lotan, R.; Anbinder, Y.; Alshiek, J.; Bennett, L.; Kostenko, M.; Landau, M.; et al. Vitamin E supplementation reduces cardiovascular events in a subgroup of middle-aged individuals with both type 2 diabetes mellitus and the haptoglobin 2-2 genotype. Arterioscler. Thromb. Vasc. Biol. 2008, 28, 341-347. [CrossRef] [PubMed]

196. Miller, E.R.; Pastor-Barriuso, R.; Dalal, D.; Riemersma, R.A.; Appel, L.J.; Guallar, E. Meta-analysis: High-dosage vitamin E supplementation may increase all-cause mortality. Ann. Intern. Med. 2005, 142, 37. [CrossRef] [PubMed]

197. Crutchley, D.J.; Que, B.G. Copper-induced tissue factor expression in human monocytic THP-1 cells and its inhibition by antioxidants. Circulation 1995, 92, 238-243. [CrossRef]

198. Ferro, D.; Basili, S.; Praticó, D.; Iuliano, L.; FitzGerald, G.A.; Violi, F. Vitamin E reduces monocyte tissue factor expression in cirrhotic patients. Blood 1999, 93, 2945-2950. [CrossRef]

199. Castilla, P.; Dávalos, A.; Teruel, J.L.; Cerrato, F.; Fernández-Lucas, M.; Merino, J.L.; Sánchez-Martín, C.C.; Ortuño, J.; Lasunción, M.A. Comparative effects of dietary supplementation with red grape juice and vitamin E on production of superoxide by circulating neutrophil NADPH oxidase in hemodialysis patients. Am. J. Clin. Nutr. 2008, 87, 1053-1061. [CrossRef]

200. Cariello, M.; Simone, S.; Loverre, A.; Gigante, M.; Incampo, F.; Pietanza, S.; Colucci, M.; Schena, F.P.; Gesualdo, L.; Grandaliano, G.; et al. Coagulation activation is associated with nicotinamide adenine dinucleotide phosphate oxidase-dependent reactive oxygen species generation in hemodialysis patients. Antioxid. Redox Signal. 2012, 16, 428-439. [CrossRef]

201. Yoshitomi, T.; Yamaguchi, Y.; Kikuchi, A.; Nagasaki, Y. Creation of a blood-compatible surface: A novel strategy for suppressing blood activation and coagulation using a nitroxide radical-containing polymer with reactive oxygen species scavenging activity. Acta Biomater. 2012, 8, 1323-1329. [CrossRef]

202. Xin, G.; Wei, Z.; Ji, C.; Zheng, H.; Gu, J.; Ma, L.; Huang, W.; Morris-Natschke, S.L.; Yeh, J.-L.; Zhang, R.; et al. Xanthohumol isolated from Humulus lupulus prevents thrombosis without increased bleeding risk by inhibiting platelet activation and mtDNA release. Free Radic. Biol. Med. 2017, 108, 247-257. [CrossRef] [PubMed]

203. Pomp, E.R.; Rosendaal, F.R.; Doggen, C.J.M. Alcohol consumption is associated with a decreased risk of venous thrombosis. Thromb. Haemost. 2008, 99, 59-63. [PubMed]

204. Gaborit, F.; Overvad, K.; Nørgaard, M.; Kristensen, S.; Tjønneland, A.; Severinsen, M. Alcohol intake and risk of venous thromboembolism. Thromb. Haemost. 2013, 110, 39-45. [CrossRef] [PubMed]

205. Wollny, T.; Aiello, L.; Di Tommaso, D.; Bellavia, V.; Rotilio, D.; Donati, M.B.; De Gaetano, G.; Iacoviello, L. Modulation of haemostatic function and prevention of experimental thrombosis by red wine in rats: A role for increased nitric oxide production. Br. J. Pharm. 1999, 127, 747-755. [CrossRef]

206. Gresele, P.; Pignatelli, P.; Guglielmini, G.; Carnevale, R.; Mezzasoma, A.M.; Ghiselli, A.; Momi, S.; Violi, F. Resveratrol, at concentrations attainable with moderate wine consumption, stimulates human platelet nitric oxide production. J. Nutr. 2008, 138, 1602-1608. [CrossRef]

207. Di Castelnuovo, A.; Rotondo, S.; Iacoviello, L.; Donati, M.B.; De Gaetano, G. Meta-analysis of wine and beer consumption in relation to vascular risk. Circulation 2002, 105, 2836-2844. [CrossRef]

208. Carnevale, R.; Pignatelli, P.; Nocella, C.; Loffredo, L.; Pastori, D.; Vicario, T.; Petruccioli, A.; Bartimoccia, S.; Violi, F. Extra virgin olive oil blunt post-prandial oxidative stress via NOX2 down-regulation. Atherosclerosis 2014, 235, 649-658. [CrossRef]

209. Puccetti, L.; Pasqui, A.L.; Pastorelli, M.; Bova, G.; Cercignani, M.; Palazzuoli, A.; Angori, P.; Auteri, A.; Bruni, F. Time-dependent effect of statins on platelet function in hypercholesterolaemia. Eur. J. Clin. Investig. 2002, 32, 901-908. [CrossRef]

210. Pignatelli, P.; Carnevale, R.; Pastori, D.; Cangemi, R.; Napoleone, L.; Bartimoccia, S.; Nocella, C.; Basili, S.; Violi, F. Immediate antioxidant and antiplatelet effect of atorvastatin via inhibition of Nox2. Circulation 2012, 126, 92-103. [CrossRef]

211. Patti, G.; Cannon, C.P.; Murphy, S.A.; Mega, S.; Pasceri, V.; Briguori, C.; Colombo, A.; Yun, K.H.; Jeong, M.H.; Kim, J.-S.; et al. Clinical benefit of statin pretreatment in patients undergoing percutaneous coronary intervention. Circulation 2011, 123, 1622-1632. [CrossRef]

212. Kessinger, C.W.; Kim, J.W.; Henke, P.K.; Thompson, B.; McCarthy, J.R.; Hara, T.; Sillesen, M.; Margey, R.J.P.; Libby, P.; Weissleder, R.; et al. Statins improve the resolution of established murine venous thrombosis: Reductions in thrombus burden and vein wall scarring. PLoS ONE 2015, 10, e0116621. [CrossRef] 
213. Basili, S.; Pignatelli, P.; Tanzilli, G.; Mangieri, E.; Carnevale, R.; Nocella, C.; Di Santo, S.; Pastori, D.; Ferroni, P.; Violi, F. Anoxia-reoxygenation enhances platelet thromboxane $\mathrm{A}_{2}$ production via reactive oxygen species-generated NOX2. Arterioscler. Thromb. Vasc. Biol. 2011, 31, 1766-1771. [CrossRef] [PubMed]

214. Cammisotto, V.; Carnevale, R.; Nocella, C.; Stefanini, L.; Bartimoccia, S.; Coluccia, A.; Silvestri, R.; Pignatelli, P.; Pastori, D.; Violi, F. Nox2-mediated platelet activation by glycoprotein (GP) VI: Effect of rivaroxaban alone and in combination with aspirin. Biochem. Pharm. 2019, 163, 111-118. [CrossRef] [PubMed]

215. Metcalfe, C.; Ramasubramoni, A.; Pula, G.; Harper, M.T.; Mundell, S.J.; Coxon, C.H. Thioredoxin inhibitors attenuate platelet function and thrombus formation. PLoS ONE 2016, 11, e0163006. [CrossRef] [PubMed]

216. Vitseva, O.; Flockhart, D.A.; Jin, Y.; Varghese, S.; Freedman, J.E. The effects of tamoxifen and its metabolites on platelet function and release of reactive oxygen intermediates. J. Pharm. Exp. 2004, 312, 1144-1150. [CrossRef]

217. SMART—Servier Medical ART. Available online: https://smart.servier.com/ (accessed on 30 October 2019).

(C) 2020 by the authors. Licensee MDPI, Basel, Switzerland. This article is an open access article distributed under the terms and conditions of the Creative Commons Attribution (CC BY) license (http://creativecommons.org/licenses/by/4.0/). 